Prepared in cooperation with the National Park Service

\title{
Water Quality of the Upper Delaware Scenic and Recreational River and Tributary Streams, New York and Pennsylvania
}

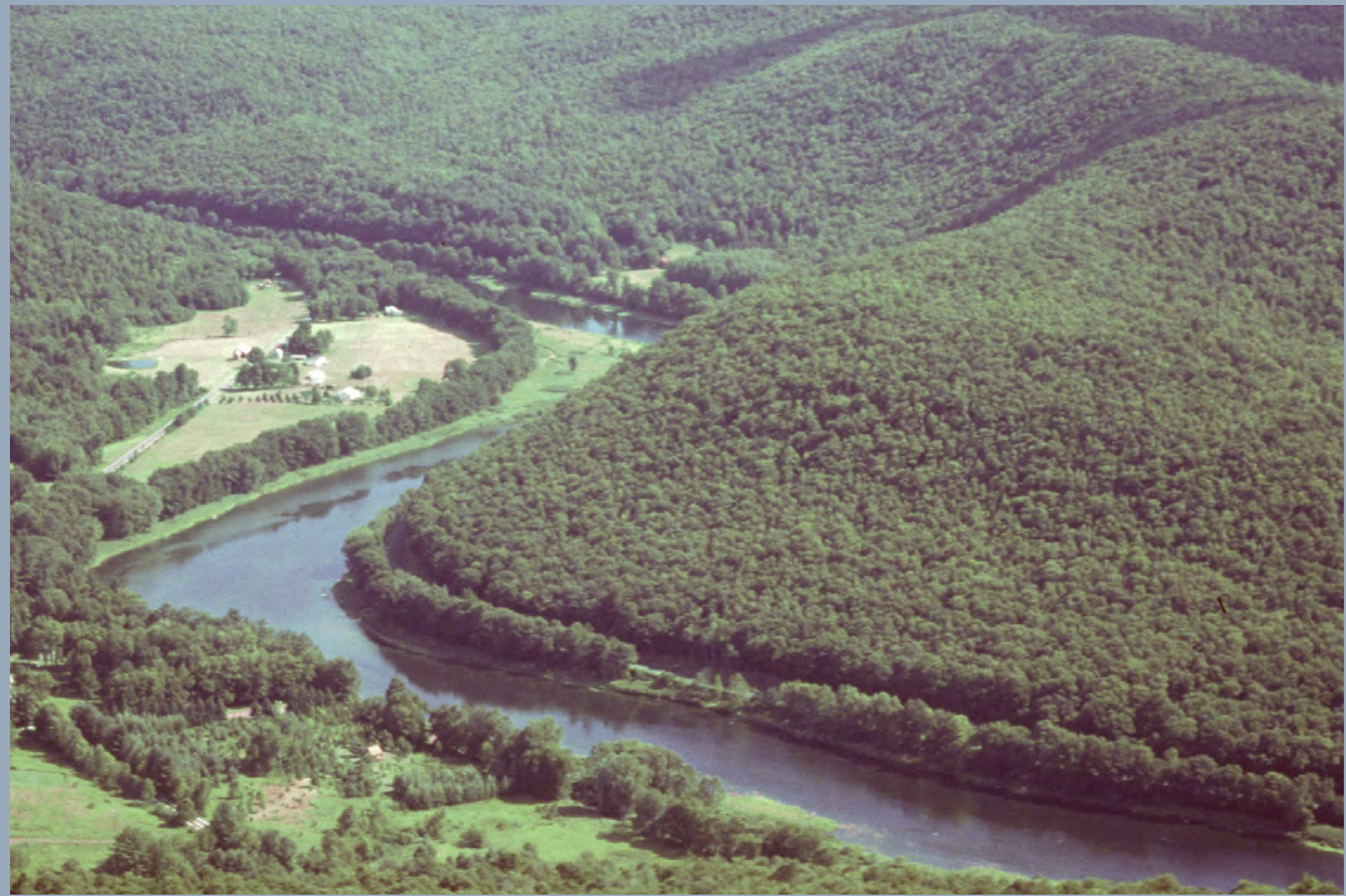

Scientific Investigations Report 2010-5009

U.S. Department of the Interior

U.S. Geological Survey 
Cover. Photograph of the Upper Delaware River, 1993, by David B. Soete, Upper Delaware Council, Narrowsburg, NY. 


\section{Water Quality of the Upper Delaware Scenic and Recreational River and Tributary Streams, New York and Pennsylvania}

By Jason Siemion and Peter S. Murdoch

Prepared in cooperation with the National Park Service

Scientific Investigations Report 2010-5009 


\title{
U.S. Department of the Interior \\ KEN SALAZAR, Secretary \\ U.S. Geological Survey \\ Marcia K. McNutt, Director
}

\section{U.S. Geological Survey, Reston, Virginia: 2010}

\author{
For more information on the USGS — the Federal source for science about the Earth, its natural and living resources, \\ natural hazards, and the environment, visit http://www.usgs.gov or call 1-888-ASK-USGS \\ For an overview of USGS information products, including maps, imagery, and publications, \\ visit http://www.usgs.gov/pubprod \\ To order this and other USGS information products, visit http://store.usgs.gov
}

\begin{abstract}
Any use of trade, product, or firm names is for descriptive purposes only and does not imply endorsement by the U.S. Government.

Although this report is in the public domain, permission must be secured from the individual copyright owners to reproduce any copyrighted materials contained within this report.
\end{abstract}

Suggested citation:

Siemion, Jason, and Murdoch, P.S., 2010, Water quality of the Upper Delaware Scenic and Recreational River and tributary streams, New York and Pennsylvania: U.S. Geological Survey Scientific Investigations Report 2010-5009, 43 p., available online only at http://pubs.usgs.gov/sir/2010/5009/. 


\section{Contents}

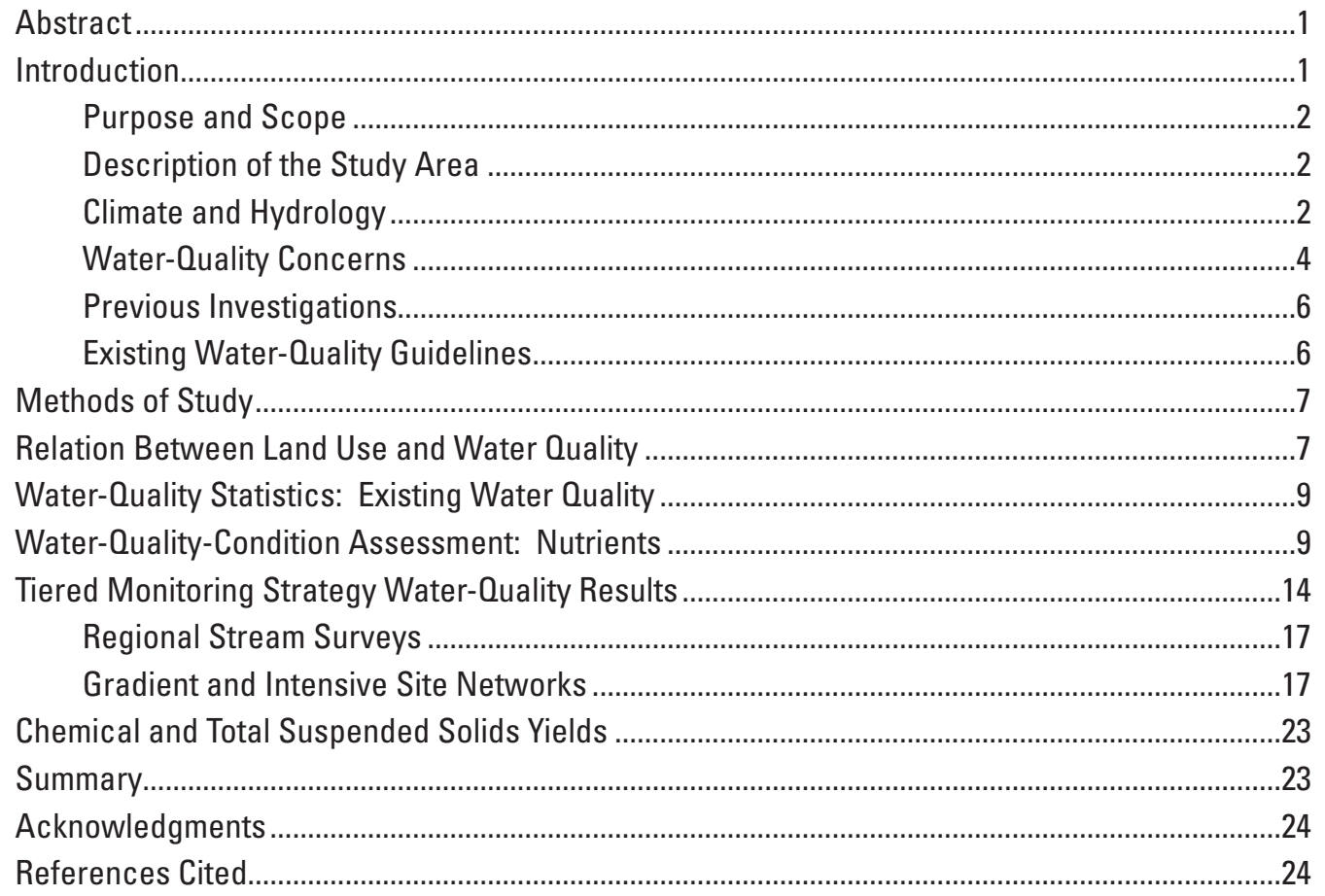

Appendix 1. Land Use in Drainage Areas of Sites Sampled during the Upper Delaware River (UPDE) Study

Appendix 2. Water-Quality Statistics for the Intensive and Gradient Study Sites, Upper Delaware River Basin, October 2005 to September 2007

Appendix 3. Yields of Selected Constituents for Intensive Sites in the Upper Delaware River Basin, October 2005 to September 2007.

\section{Figures}

1. Map showing location of the Upper Delaware River (UPDE) drainage basin, intensive and gradient study basins, and mainstem intensive, tributary intensive, tributary gradient, and tributary regional survey sampling sites.

2. Graph showing streamflow at the Delaware River at Port Jervis, N.Y., during water years 2006 and 2007, and dates of sample collection

3. Map showing land use/land cover, intensive and gradient mainstem and tributary basins, and sampling-site locations in the Upper Delaware River drainage basin......

4. Diagrams showing distributions of $(A)$ acid neutralizing capacity, aluminum, ammonium, boron, and calcium; (B) chloride, dissolved organic carbon, magnesium, nitrate, and particulate organic carbon; (C) pH, potassium, specific conductance, silicon, and sodium; and (D) sulfate, total dissolved nitrogen, total phosphorous, total suspended solids, and turbidity measured at intensive and gradient sites in the Upper Delaware River (UPDE) drainage basin, water years 2006 and 2007. 
5. Map showing classifications of water quality with respect to nitrate concentration in the Upper Delaware River (UPDE) tributary basins, water years 2006 and 2007.

6. Map showing classifications of water quality with respect to total phosphorous concentration in the Upper Delaware River (UPDE) tributary basins, water years 2006 and 2007.

7. Graphs showing regional cumulative curves of basin area ranked by increasing nitrate concentration for (A) spring 2006 high flow, (B) summer 2006 base flow, (C) spring 2007 high flow, and (D) summer 2007 base flow with box plots for selected gradient sites for the Upper Delaware River (UPDE) tributaries.

8. Graphs showing cumulative frequency curves of nitrate concentration, total phosphorous concentration, $\mathrm{pH}$, specific conductance, and total suspended solids concentration for different land uses in the Upper Delaware River (UPDE) drainage basin.

9. Graphs showing site-specific cumulative frequency curves of nitrate concentration, total phosphorous concentration, $\mathrm{pH}$, specific conductance, and total suspended solids concentration for agricultural sites in the Upper Delaware River (UPDE) drainage basin.

10. Graphs showing site-specific cumulative frequency curves of nitrate concentration, total phosphorous concentration, $\mathrm{pH}$, specific conductance, and total suspended solids concentration for forested sites in the Upper Delaware River (UPDE) drainage basin.

11. Graphs showing site-specific cumulative frequency curves of nitrate concentration, total phosphorous concentration, $\mathrm{pH}$, specific conductance, and total suspended solids concentration for suburbanized sites in the Upper Delaware River (UPDE) drainage basin

12. Graph showing spatial-temporal cumulative curves for nitrate and total phosphorous concentrations in the Upper Delaware River (UPDE) drainage basin and an example theorized ideal curve.

\section{Tables}

1. Mean annual air temperature and mean annual precipitation for three sites over an elevation gradient in the Upper Delaware River (UPDE) drainage basin, 1970-2000

2. Annual mean air temperature, maximum daily temperature, minimum daily temperature, total precipitation, and maximum daily rainfall for three sites over an elevation gradient in the Upper Delaware River (UPDE) drainage basin.

3. Peak discharge for selected sites in the Upper Delaware River (UPDE) drainage basin during the June 2006 flood and median annual peak flow.

4. Scenic Rivers Monitoring Program definition of water quality for selected constituents and properties in the Delaware River between the confluence of the East Branch and West Branch Delaware River and Port Jervis, N.Y.

5. Values of selected common constituents and properties for original Scenic Rivers Monitoring Program (SRMP) water quality (Delaware River Basin Commission, 2008b), existing main stem Delaware River water quality, nutrient criteria (Smith and others, 2006), and U.S. Environmental Protection Agency (USEPA)

ecoregional reference conditions. 


\section{Conversion Factors, Datum, and Abbreviations}

\begin{tabular}{lll}
\hline Multiply & By & To obtain \\
\hline & Length & \\
\hline centimeter $(\mathrm{cm})$ & 0.3937 & inch (in.) \\
meter $(\mathrm{m})$ & 3.281 & foot $(\mathrm{ft})$ \\
kilometer $(\mathrm{km})$ & 0.6214 & mile $(\mathrm{mi})$ \\
hectare $(\mathrm{ha})$ & 0.003861 & square mile $\left(\mathrm{mi}^{2}\right)$ \\
square kilometer $\left(\mathrm{km}^{2}\right)$ & 0.3861 & square mile $\left(\mathrm{mi}^{2}\right)$ \\
\hline & Flow rate & \\
\hline cubic meter per second $\left(\mathrm{m}^{3} / \mathrm{s}\right)$ & 35.31 & cubic foot per second $\left(\mathrm{ft}^{3} / \mathrm{s}\right)$ \\
\hline & Mass & \\
\hline kilogram $(\mathrm{kg})$ & 2.205 & pound avoirdupois $(\mathrm{lb})$ \\
megagram $(\mathrm{Mg})$ & 1.102 & ton, short $(2,000 \mathrm{lb})$ \\
\hline
\end{tabular}

Temperature in degrees Celsius $\left({ }^{\circ} \mathrm{C}\right)$ may be converted to degrees Fahrenheit $\left({ }^{\circ} \mathrm{F}\right)$ as follows:

$$
{ }^{\circ} \mathrm{F}=\left(1.8 x^{\circ} \mathrm{C}\right)+32
$$

Specific conductance is given in microsiemens per centimeter at 25 degrees Celsius $\left(\mu \mathrm{S} / \mathrm{cm}\right.$ at $\left.25^{\circ} \mathrm{C}\right)$.

Concentrations of chemical constituents in water are given in milligrams per liter (mg/L).

Vertical coordinate information is referenced to the North American Vertical Datum of 1983 (NAVD 83).

Horizontal coordinate information is referenced to the North American Datum of 1983 (NAD 83).

Elevation, as used in this report, refers to distance above the vertical datum.

$\begin{array}{ll}\text { Abbreviations used in this report } \\ \text { ANC } & \text { Acid neutralizing capacity } \\ \text { DRBC } & \text { Delaware River Basin Commission } \\ \mathrm{kg} / \mathrm{ha} & \text { kilograms per hectare } \\ \text { NA } & \text { Not available } \\ \text { NPS } & \text { National Park Service } \\ \mathrm{r}^{2} & \text { Coefficient of determination } \\ \text { SPW } & \text { Special Protection Waters } \\ \text { SRMP } & \text { Scenic Rivers Monitoring Program } \\ \text { UPDE } & \text { Upper Delaware Scenic and Recreational River } \\ \text { USEPA } & \text { U.S. Environmental Protection Agency } \\ \text { USGS } & \text { U.S. Geological Survey }\end{array}$


This page has been left blank intentionally. 


\title{
Water Quality of the Upper Delaware Scenic and Recreational River and Tributary Streams, New York and Pennsylvania
}

\author{
By Jason Siemion and Peter S. Murdoch
}

\section{Abstract}

Water-quality samples were collected from the Upper Delaware Scenic and Recreational River (UPDE) and its tributaries during the period October 1, 2005, to September 30, 2007 , to document existing water quality, determine relations between land use and water quality, and identify areas of water-quality concern. A tiered water-quality monitoring framework was used, with the tiers consisting of intensively sampled sites, gradient sites representing the range of land uses present in the basin, and regional stream-survey sites.

Median nitrate and total phosphorous concentrations were 1.15 and $0.01 \mathrm{mg} / \mathrm{L}$ (milligrams per liter) for three sites on the mainstem Delaware River, 1.27 and $0.009 \mathrm{mg} / \mathrm{L}$ for the East Branch Delaware River, 2.04 and $0.01 \mathrm{mg} / \mathrm{L}$ for the West Branch Delaware River, and 0.68 and $0.006 \mathrm{mg} / \mathrm{L}$ for eight tributaries that represent the range of land uses present in the basin, respectively. The percentage of agricultural land varied by basin from 0 to 30 percent and the percentage of suburbanization varied from 0 to 17 percent. There was a positive correlation between the percentage of agricultural land use in a basin and observed concentrations of acid neutralizing capacity, calcium, potassium, nitrate, and total dissolved nitrogen, whereas no correlation between the percentage of suburbanization and water quality was detected.

Results of stream surveys showed that nitrate concentrations in 55 to 65 percent of the UPDE Basin exceeded the nitrate reference condition and a suggested water-quality guideline for ecological impairment in New York State $(0.98 \mathrm{mg} / \mathrm{L})$ during the spring. Many of the affected parts of the basin were more than 90 percent forested and showed signs of episodic acidification, indicating that the long-term effects of acid deposition play a role in the high nitrate levels. Nitrate concentrations in 75 percent of samples collected from agricultural sites exceeded the suggested nitrate water-quality guideline for ecological impairment. Concentrations of nitrate and total phosphorous in samples collected from agricultural sites also were twice and 25 percent higher than those in samples from reference sites, respectively.

\section{Introduction}

The Upper Delaware Scenic and Recreational River (UPDE) is a $118-\mathrm{km}$ section of the uppermost mainstem reach of the Delaware River, designated by Congress in 1978 to protect its high water quality and natural and cultural resources under the Wild and Scenic Rivers Act (Conference of Upper Delaware Townships, 1986). A 225- $\mathrm{km}^{2}$ river corridor was established to meet the resource-protection requirements of the Act, but the National Park Service (NPS) owns only a small portion of the land within this corridor, and therefore relies largely on the Special Protection Waters (SPW) designation and local zoning to protect the resource and its water-quality values (Conference of Upper Delaware Townships, 1986). "The Delaware River Basin Commission (DRBC) adopted Special Protection Waters regulations in 1992 for point source (or "end-of-pipe") discharges and in 1994 for non-point source pollutant loadings carried by runoff to protect existing high water quality in areas of the Delaware River Basin deemed to have exceptionally high scenic, recreational, ecological and (or) water supply values" (Delaware River Basin Commission, 2008a). SPW regulations are based on a whole-drainagebasin management approach in which new contaminant loadings are reduced or eliminated to maintain existing water quality or move water quality to more natural conditions (Delaware River Basin Commission, 2004 and 2008b). A detailed description of SPW regulations is available from the DRBC (2008a).

The Scenic Rivers Monitoring Program (SRMP) was initiated in 1984 by the DRBC and NPS to monitor water quality in a 195-km segment of the Delaware River and its tributaries, including the UPDE (Delaware River Basin Commission, 2004). As part of the SRMP, samples were collected at a set of boundary and intrastate control points (tributary mouths and sites along the mainstem Delaware River) and reach-wide existing water quality was assessed as the mean and 95-percent confidence limits of the mean (Delaware River Basin Commission, 2004). Problems with the assessment led the DRBC to determine that existing 
water quality needed to be documented as a basis for sitespecific concentration and loading targets, and that new SPW regulations would be established in terms of medians and the 95-percent confidence limits of the median.

To help meet this need, the U.S. Geological Survey (USGS), in cooperation with the NPS, applied a tiered monitoring framework that follows the example established for the Delaware River Basin through the Collaborative Environmental Monitoring and Research Initiative (Murdoch and others, 2008). In this data-collection framework, intensively monitored streamgages are nested within regional surveys to cost-effectively monitor both temporal and spatial variability in ecosystem properties.

Resource management requires the use of sitespecific data, whereas policy decisions require regional characterizations (Olsen and others, 1999). Intensive and gradient water-quality sampling was used to define existing water quality for specific sites. Cumulative curves were generated to describe property conditions in the population of sampling sites, allowing the intensively sampled sites to be placed in a regional context (Herlihy and others, 2000). This combination of site-specific and survey data allowed for an improved assessment of water quality, providing scientific support for management decisions (Bolgrien and others, 2005). Additionally, as part of the project, the watershed area for each river reach and tributary sampled in the study was delineated, land use within each watershed (percent agricultural, forest, and suburban) was determined, and maps of water-quality status were developed.

\section{Purpose and Scope}

The purpose of this report is to describe existing water quality, relations between land use and water quality, and areas of water-quality concern within the UPDE and its tributaries during water years 2006 and 2007. (A water year is the period from October 1 to September 30, and is designated by the calendar year in which it ends.) Major ions, nutrients, $\mathrm{pH}$, acid neutralizing capacity (ANC), and total suspended solids are the water-quality constituents and properties discussed in the report. Summary statistics, box plots, and cumulative curves are used to describe water quality at each of 13 intensively monitored sites as well as more than 40 stream-survey sites. A detailed discussion of the use of cumulative curves to assess changes in future water quality also is provided.

\section{Description of the Study Area}

The reach of the Delaware River included in the study extends from just upstream from the confluence of the east and west branches of the Delaware River downstream to Port Jervis, N.Y. (fig. 1). The total drainage area upstream from the Port Jervis sampling location is $7,960 \mathrm{~km}^{2}, 3,567 \mathrm{~km}^{2}$ of which drains into the UPDE through the east and west branches of the Delaware River. This drainage area is dominated by forested landscapes (about 80 percent) with some agriculture (about 10 percent) and a small amount of suburbanized land (about 5 percent). Although the percentage of the study area that is suburbanized is currently small, it is increasing and is concentrated along river corridors. The population in the Pennsylvania counties bordering the river (Pike and Wayne Counties) increased by 100 and 25 percent, respectively, from 1990 to 2005 (U.S. Census Bureau, 2008).

The watersheds that drain to the study area make up the northernmost portion of the Appalachian Plateau physiographic province. The east and west branches of the Delaware River drain the western portions of the Catskill Mountains, with elevations ranging from 300 to $1,200 \mathrm{~m}$. Bedrock in this area consists primarily of nearly flat-lying sandstone, shale, and conglomerate with thin soils on ridge tops. Both the east and west branches of the Delaware River are dammed to provide drinking water for New York City, with the outflows regulated to maintain minimum flows to downstream users. The Lackawaxen River drains a portion of the Pocono Plateau and is the third largest tributary that drains to the study area. Flows in a portion of the Lackawaxen Basin are regulated for power generation, as is the Mongaup River, the fourth largest tributary to the UPDE.

The Delaware River is the only major river along the Atlantic Coast that remains undammed along its entire mainstem $(533 \mathrm{~km})$, allowing anadromous and catadromous fish access to historic habitat (as on few other river systems of this size in the eastern United States) and maintaining much of its rich native biodiversity. Water quality in the river's upper reaches is good, supporting fisheries and recreational resources. The Upper Delaware has been acclaimed as one of the most prolific wild trout rivers east of the Mississippi River (Novick, 1993), supports populations of the federally endangered dwarf wedge mussel, and is one of the largest and most important inland bald eagle wintering habitats in the eastern United States (P.E. Nye, New York State Department of Environmental Conservation Endangered Species Unit, written commun., 1996).

\section{Climate and Hydrology}

Mean annual air temperature and precipitation at three sites over an elevation gradient in the UPDE Basin for the period 1970 to 2000 are given in table 1 . The annual mean air temperature, maximum daily temperature, minimum daily temperature, total precipitation, departure from normal precipitation, and maximum daily rainfall for the same sites for 2006 and 2007 are given in table 2. Precipitation was evenly distributed throughout the year, with the bulk of snow falling from December to March.

The hydrograph for the study period at the Delaware River at Port Jervis streamgage is shown in figure 2 as an example of the flow conditions during the study. A regionwide flood event took place in late June 2006. Major tributaries experienced initial rises on June 25th and peak 


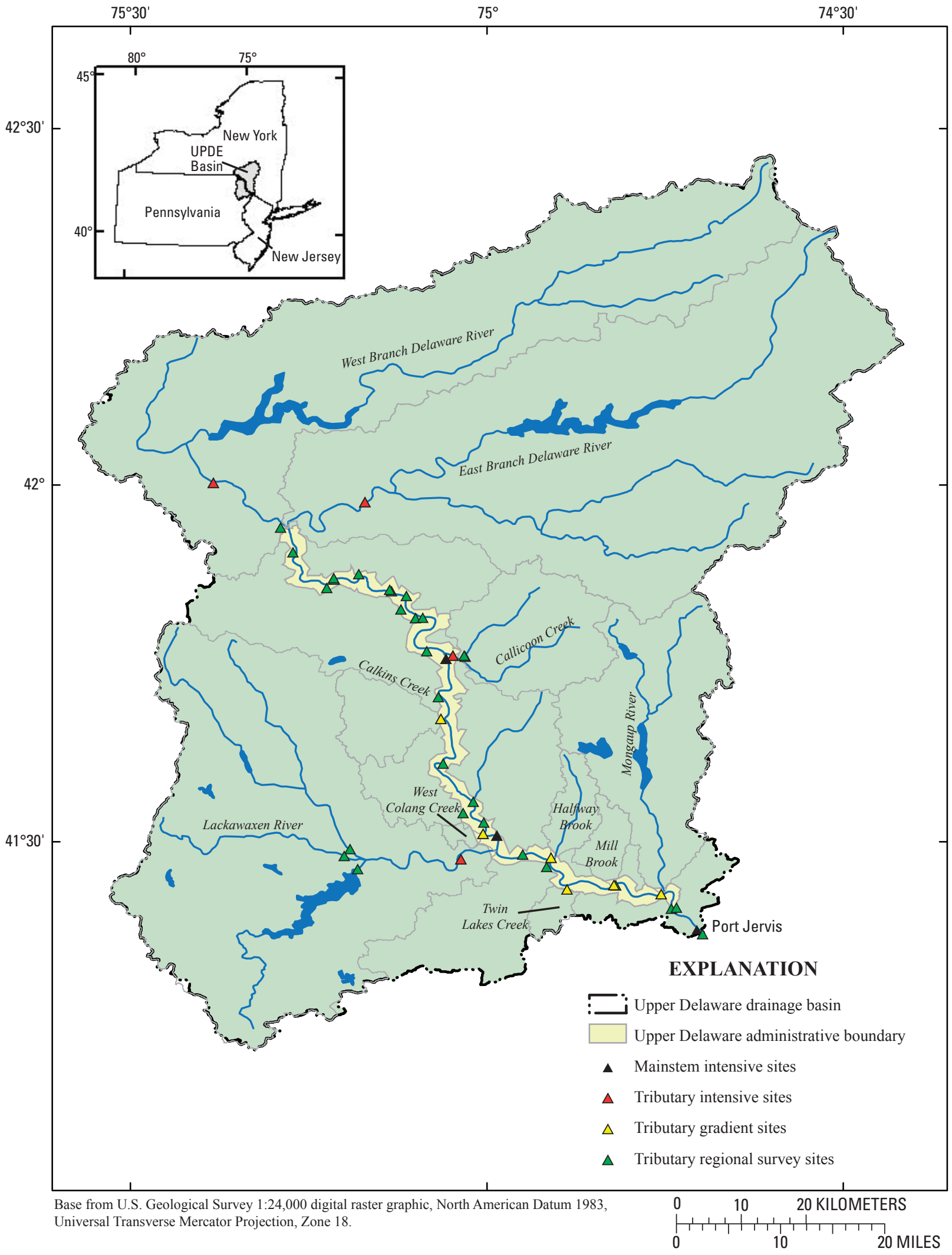

Figure 1. Location of the Upper Delaware River (UPDE) drainage basin, intensive and gradient study basins, and mainstem intensive, tributary intensive, tributary gradient, and tributary regional survey sampling sites. 
Table 1. Mean annual air temperature and mean annual precipitation for three sites over an elevation gradient in the Upper Delaware River (UPDE) drainage basin, 1970-2000.

[Data from National Climatic Data Center, 2008; ${ }^{\circ} \mathrm{C}$, degrees Celsius; cm, centimeters; m, meters]

\begin{tabular}{lccc}
\hline Site & $\begin{array}{c}\text { Mean } \\
\text { annual } \\
\text { air temperature } \\
\left({ }^{\circ} \mathbf{C}\right)\end{array}$ & $\begin{array}{c}\text { Mean } \\
\text { annual } \\
\text { precipitation } \\
(\mathbf{c m})\end{array}$ & $\begin{array}{c}\text { Elevation } \\
\text { of } \\
\text { monitoring site } \\
(\mathbf{m})\end{array}$ \\
\hline Port Jervis, NY & 10.0 & 116.9 & 143 \\
Delhi, NY & 7.2 & 109.7 & 432 \\
Slide Mountain, NY & 5.2 & 161.6 & 808 \\
\hline
\end{tabular}

Table 2. Annual mean air temperature, maximum daily temperature, minimum daily temperature, total precipitation, and maximum daily rainfall for three sites over an elevation gradient in the Upper Delaware River (UPDE) drainage basin.

[Data from National Climatic Data Center, 2008; ${ }^{\circ} \mathrm{C}$, degrees Celsius; cm, centimeters]

\begin{tabular}{lcccccc}
\hline \multicolumn{1}{c}{ Site } & Year & $\begin{array}{c}\text { Annual } \\
\text { mean } \\
\text { air temperature } \\
\left({ }^{\circ} \mathbf{C}\right)\end{array}$ & $\begin{array}{c}\text { Maximum } \\
\text { daily } \\
\text { air temperature } \\
\left({ }^{\circ} \mathbf{C}\right)\end{array}$ & $\begin{array}{c}\text { Minimum } \\
\text { daily } \\
\text { air temperature } \\
\left({ }^{\circ} \mathbf{C}\right)\end{array}$ & $\begin{array}{c}\text { Annual } \\
\text { total } \\
\text { precipitation } \\
(\mathbf{c m})\end{array}$ & $\begin{array}{c}\text { Single day } \\
\text { maximum } \\
\text { precipitation } \\
(\mathbf{c m})\end{array}$ \\
\hline Port Jervis, NY & 2006 & 10.2 & 36.1 & -15 & 115.6 & 5.5 \\
Port Jervis, NY & 2007 & 9.6 & 35.6 & -17.2 & 115.3 & 6.8 \\
Delhi, NY & 2006 & 8.6 & 34.4 & -19.4 & 153.1 & 10.9 \\
Delhi, NY & 2007 & 7.1 & 32.8 & -23.9 & 145.2 & 6.2 \\
Slide Mountain, NY & 2006 & 6.9 & 30.6 & -20.0 & 187.1 & 8.0 \\
Slide Mountain, NY & 2007 & 6.1 & 29.4 & -23.9 & 181.1 & 12.3 \\
\hline
\end{tabular}

flows on June 28th. By July 6th, flows at most sampling sites had returned to within 5 percent of pre-storm base-flow values. This flood event was a period-of-record peak flow for many sites and had a recurrence interval of greater than 100 and less than 500 years at all the intensive sites, with the exception of the Delaware River at Port Jervis, where the recurrence interval was 80 years (Suro and others, 2009). The peak discharge at each mainstem site and the East Branch and West Branch Delaware River sites during the June 2006 flood are compared to the median annual peak flow in table 3 .

During the evening of June 19, 2007, a period of intense rainfall occurred in the watershed of the Beaver Kill, a tributary to the East Branch Delaware River in the western Catskill Mountains of New York. The occurrence of this localized, intense storm over two small headwater basins with a combined area of $35 \mathrm{~km}^{2}$ measurably influenced water quality $100 \mathrm{~km}$ downstream on the Delaware River. According to the National Weather Service, 15 to $20 \mathrm{~cm}$ of rain fell from
1630 to 1930 Eastern Standard Time, with local observations totaling 15 to $28 \mathrm{~cm}$ (Schaffner and others, 2007). National Weather Service analysis of the data indicated the event to be twice the 3-hour, 100-year rainfall extreme, with some rainfall rates exceeding $2.5 \mathrm{~cm}$ per 15 minutes (Schaffner and others, 2007). The return period for the flood in one of the affected headwater streams was estimated to be 500 years (Schaffner and others, 2007).

\section{Water-Quality Concerns}

Several stressors can affect water quality in the watersheds that drain to the UPDE, including the long-term effects of acid rain, climate change and variability, and runoff from agricultural and suburbanized lands. Each of these issues is discussed briefly below.

Although decreases in acid precipitation and associated streamwater sulfate and nitrate concentrations have been 


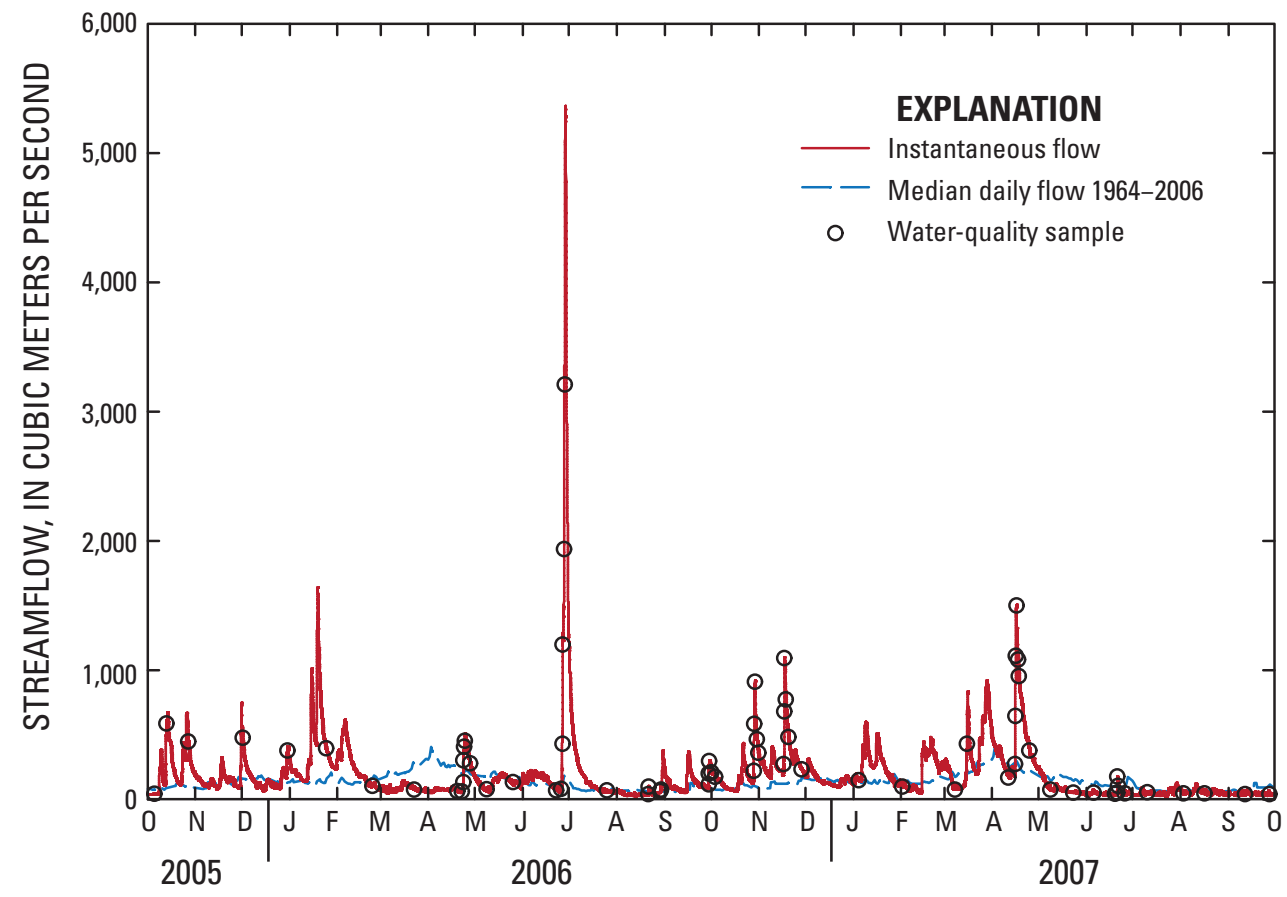

Figure 2. Streamflow at the Delaware River at Port Jervis, NY, during water years 2006 and 2007, and dates of sample collection.

Table 3. Peak discharge for selected sites in the Upper Delaware River (UPDE) drainage basin during the June 2006 flood and median annual peak flow.

$\left[\mathrm{m}^{3} / \mathrm{s}\right.$, cubic meters per second]

\begin{tabular}{|c|c|c|c|}
\hline U.S. Geological Survey streamgage and number & $\begin{array}{l}\text { Median annual } \\
\text { peak flow } \\
\left(\mathrm{m}^{3} / \mathbf{s}\right)\end{array}$ & $\begin{array}{l}2006 \text { flood-event } \\
\text { peak flow } \\
\left(\mathrm{m}^{3} / \mathrm{s}\right)\end{array}$ & $\begin{array}{l}2006 \text { flood-event } \\
\text { rank for } \\
\text { period of record }\end{array}$ \\
\hline West Branch Delaware River 01426500 & 338 & 1,230 & $2 \mathrm{~d}$ \\
\hline East Branch Delaware River 01421000 & 598 & 2,190 & 1 st \\
\hline Delaware River at Callicoon, NY 01427510 & 1,130 & 4,080 & 1 st \\
\hline Delaware River near Barryville, NY 01428500 & 1,300 & 4,280 & 1 st \\
\hline Delaware River at Port Jervis, NY 01434000 & 1,720 & 5,350 & $3 \mathrm{~d}$ \\
\hline
\end{tabular}

documented in the Catskill region during the last 20 years (Burns and others, 2006), these trends could quickly reverse if future increases in acid deposition were to occur. Future increases in acid deposition would be detected at higher flows initially (episodic), with base-flow water quality degrading more slowly over time (chronic) (Murdoch and Shanley, 2006; Stoddard, 1994).
Changing climatic conditions in the Catskill Mountains may alter the timing and volume of discharge to the UPDE through the east and west branches of the Delaware River. During the last 50 years in the Catskill region, mean annual air temperature has increased $0.6^{\circ} \mathrm{C}$, annual precipitation has increased $13.6 \mathrm{~cm}$, and peak snowmelt has shifted 2 weeks, from early April to late March (Burns and others, 2007). 
Land use in a stream's drainage basin affects the quality of water in the stream. Streams that drain forested areas tend to have lower dissolved-solids concentrations than streams that drain agricultural areas. Runoff from agricultural land typically contains higher levels of nitrate (Gburek and Folmar, 1999), total suspended solids (Ahearn and others, 2005), and total phosphorous (Gelbrecht and others, 2005) than runoff from forested land. The percentage of urbanization in a watershed has been shown to positively correlate with fecal coliform levels (Mehaffey and others, 2005) and total suspended solids concentrations (Ahearn and others, 2005). The combined effects of climate change and anthropogenic changes in the landscape are likely to alter the hydrologic and biogeochemical processes in the UPDE (Moore and others, 1997).

\section{Previous Investigations}

A study of water quality in the Delaware River Basin was conducted as part of the USGS National Water Quality Assessment Program during 1998-2001 (Fischer and others, 2004). Nutrient, pesticide, and volatile organic compound concentrations were measured in selected streams throughout the basin. Nutrient and pesticide levels in samples from watersheds dominated by urban and agricultural land uses were found to be elevated above those in samples from forested watersheds. Volatile organic compounds were detected in sediments from many streams, and in fish tissues. Samples of fish tissues from one-quarter of the sites sampled contained mercury at levels exceeding those considered safe for human consumption.

The New York State Department of Environmental Conservation Stream Biomonitoring Unit conducted a macroinvertebrate biological assessment of the West Branch Delaware River in 2004 and concluded that all six sites visited were non-impacted by water-quality degradation (Bode and others, 2006). The same group examined 30 -year trends in water quality based on macroinvertebrate studies for 21 of the sites in the UPDE study (Bode and others, 2004); all of the sites were assessed as being either non-impacted (14 sites) or "slightly impacted" (7 sites) by water-quality degradation as of 1999. The slightly impacted sites included Beaver Brook, Delaware River at Pond Eddy, Delaware River at Port Jervis, East Branch Delaware River at Fishs Eddy, Halfway Brook, Hankins Creek, and Ten Mile River.

\section{Existing Water-Quality Guidelines}

The Scenic Rivers Monitoring Program data collection resulted in initial Special Protection Waters regulations for the UPDE. These reach-wide regulations are shown in table 4.

The U.S. Environmental Protection Agency (USEPA) has established ecoregional reference conditions for assessing concentrations of total nitrogen and total phosphorous. The study area is in USEPA Ecoregion VIII. The ecoregional reference conditions for Ecoregion VIII are $0.38 \mathrm{mg} / \mathrm{L}$ for total nitrogen and $0.01 \mathrm{mg} / \mathrm{L}$ for total phosphorous (U.S. Environmental Protection Agency, 2001).

Table 4. Scenic Rivers Monitoring Program definition of water quality for selected constituents and properties in the Delaware River between the confluence of the East Branch and West Branch Delaware River and Port Jervis, NY.

[From Delaware River Basin Commission, 2008b; $\mu \mathrm{S} / \mathrm{cm}$, microsiemens per centimeter at $25^{\circ}$ Celsius; mg/L, milligrams per liter]

\begin{tabular}{|c|c|c|c|c|}
\hline Property & Mean & $\begin{array}{l}\text { 95-percent confidence } \\
\text { limits of mean }\end{array}$ & $\begin{array}{l}\text { 10th and 90th } \\
\text { percentiles }\end{array}$ & Comments \\
\hline Conductivity $(\mu \mathrm{S} / \mathrm{cm})$ & 68 & 66.6 to 69.3 & 52 and 88 & $\begin{array}{l}\text { Non-seasonal; } \\
\text { reachwide }\end{array}$ \\
\hline Total suspended solids (mg/L) & 4.0 & 2.9 to 5.6 & 2.0 and 16 & $\begin{array}{l}\text { Non-seasonal; } \\
\text { reachwide }\end{array}$ \\
\hline Total phosphorous (mg/L) & 0.029 & 0.027 to 0.031 & 0.018 and 0.05 & $\begin{array}{l}\text { Non-seasonal; } \\
\text { reachwide }\end{array}$ \\
\hline Ammonia + ammonium $(\mathrm{mg} / \mathrm{L})$ & 0.015 & 0.013 to 0.018 & 0.01 and 0.05 & $\begin{array}{l}\text { As nitrogen; } \\
\text { May-Sept; } \\
\text { reachwide }\end{array}$ \\
\hline Ammonia + ammonium $(\mathrm{mg} / \mathrm{L})$ & 0.022 & 0.02 to 0.025 & 0.01 and 0.06 & $\begin{array}{l}\text { As nitrogen; } \\
\text { non-seasonal; } \\
\text { reachwide }\end{array}$ \\
\hline
\end{tabular}


A nutrient biotic index (NBI) for use with benthic macroinvertebrate communities was developed by Smith and others (2006). This index established nutrient tolerances based on distributions of 164 macroinvertebrate taxa over nitrate and total phosphorous gradients in New York State wadeable streams, including streams in the UPDE. Smith and others (2006) describe mesotrophic and eutrophic thresholds of 0.24 and $0.98 \mathrm{mg} / \mathrm{L}$, respectively, for nitrate and 0.0175 and $0.065 \mathrm{mg} / \mathrm{L}$, respectively, for total phosphorous, and suggest that streams in which nutrient levels exceed the eutrophic threshold be considered threatened by nutrient impairment.

In this report, the USEPA ecoregional water-quality criteria and the NBI of Smith and others (2006) are used as standards with which to compare existing water quality in the UPDE.

\section{Methods of Study}

The water-quality data for this study were collected using the previously mentioned tiered monitoring framework. The top tier consisted of seven intensively monitored sites where short-term temporal variability in streamwater quality was assessed from samples collected with automated samplers during storms and snowmelt. These sites included the East Branch and West Branch Delaware River at a point just upstream from the UPDE administrative boundary, three mainstem Delaware River sites distributed along the length of the study reach, and two additional tributary sites. The middle tier consisted of 13 sites representing the range (or gradient) of observed water-quality conditions at which samples were collected manually on a monthly basis. This gradient sampling network included the intensive sites as well as six tributary sites that represent agricultural, forested, and suburban land uses. The third monitoring tier consisted of a synoptic regional stream survey of all major tributaries to the UPDE as well as a set of sampling points along the mainstem Delaware River. Samples were collected at these sites once during spring high flow and once during summer base flow during both years of the study. Sampling sites are listed in appendix 1.

Sampling points for all tributary basins were located as near the confluence with the mainstem Delaware River as possible, with exceptions made for co-location of sites with existing streamgages. During high-flow sample collection, manual-sampling locations were adjusted to avoid backwater influences from the mainstem Delaware River. Although the samples collected at these locations were point samples, they represented the integration of influences on water quality within the entire watershed that drains to the stream (Herlihy and others, 2000). Samples were collected using standard USGS methods (U.S. Geological Survey, 2006).

All samples were analyzed for nutrients, major ions, $\mathrm{pH}$, conductivity, dissolved organic carbon, particulate organic carbon, total suspended solids, and turbidity at the USGS New York Water Science Center water-quality laboratory, using standard methods (Lawrence and others, 1995). In addition, monthly samples collected at the gradient sites were analyzed for total phosphorous at the USGS National Water Quality Laboratory in Denver, Colorado.

Stage-discharge relations were developed for the gradient sites that were not co-located at existing streamgages in order to obtain concurrent flow measurements for each sample. Stage-discharge relations were developed using standard USGS methods (Rantz and others, 1982), with at least five flow measurements made. Instrumentation at intensive sites recorded instantaneous stage, water temperature, and specific conductance at 15-minute intervals. Fifteen-minute discharge was determined based on established stage-discharge relations for each site.

Annual chemical loads for intensive sites were calculated in steps: (1) 15-minute analyte concentrations were derived from linear interpolation of concentrations measured in sequential water samples; (2) 15-minute discharges corresponding to the derived concentrations were multiplied by those concentrations to produce an instantaneous load; (3) the instantaneous load was multiplied by 15 minutes to represent the period from 7.5 minutes before to 7.5 minutes after the time of the derived concentration; and (4) the 15-minute loads were summed over the course of the water year to produce an annual load. Summary Statistics were computed using S-Plus statistical analysis software (Insightful Corporation, 2005).

\section{Relation Between Land Use and Water Quality}

The land use for each tributary watershed and selected sites along the mainstem of the Delaware River is shown in figure 3 and percentages are provided in appendix 1. Land use was determined using the 2001 National Land Cover Dataset. Most of the agriculture in the UPDE Basin was contained within the basins of four tributaries: the West Branch Delaware River, Callicoon Creek, Calkins Creek, and the Lackawaxen River. The study watersheds with the highest percentage of suburbanization were West Colang Creek and Twin Lakes Creek. The small towns along the length of the mainstem Delaware River and the East Branch and West Branch Delaware River make up a small percentage of the overall land use, and large upstream contributions to river flow likely minimize the effects of these suburban areas on downstream water quality. Localized effects on water quality from these towns were not investigated.

Relations between land use and chemical concentrations were examined for the sites on tributaries to the UPDE. Acid neutralizing capacity and concentrations of calcium, potassium, nitrate, total dissolved nitrogen, and dissolved phosphorous were all positively correlated with the percentage of the basin occupied by agricultural land use. The coefficient of determination $\left(\mathrm{r}^{2}\right)$ values, which ranged from 0.25 to 0.5 , 


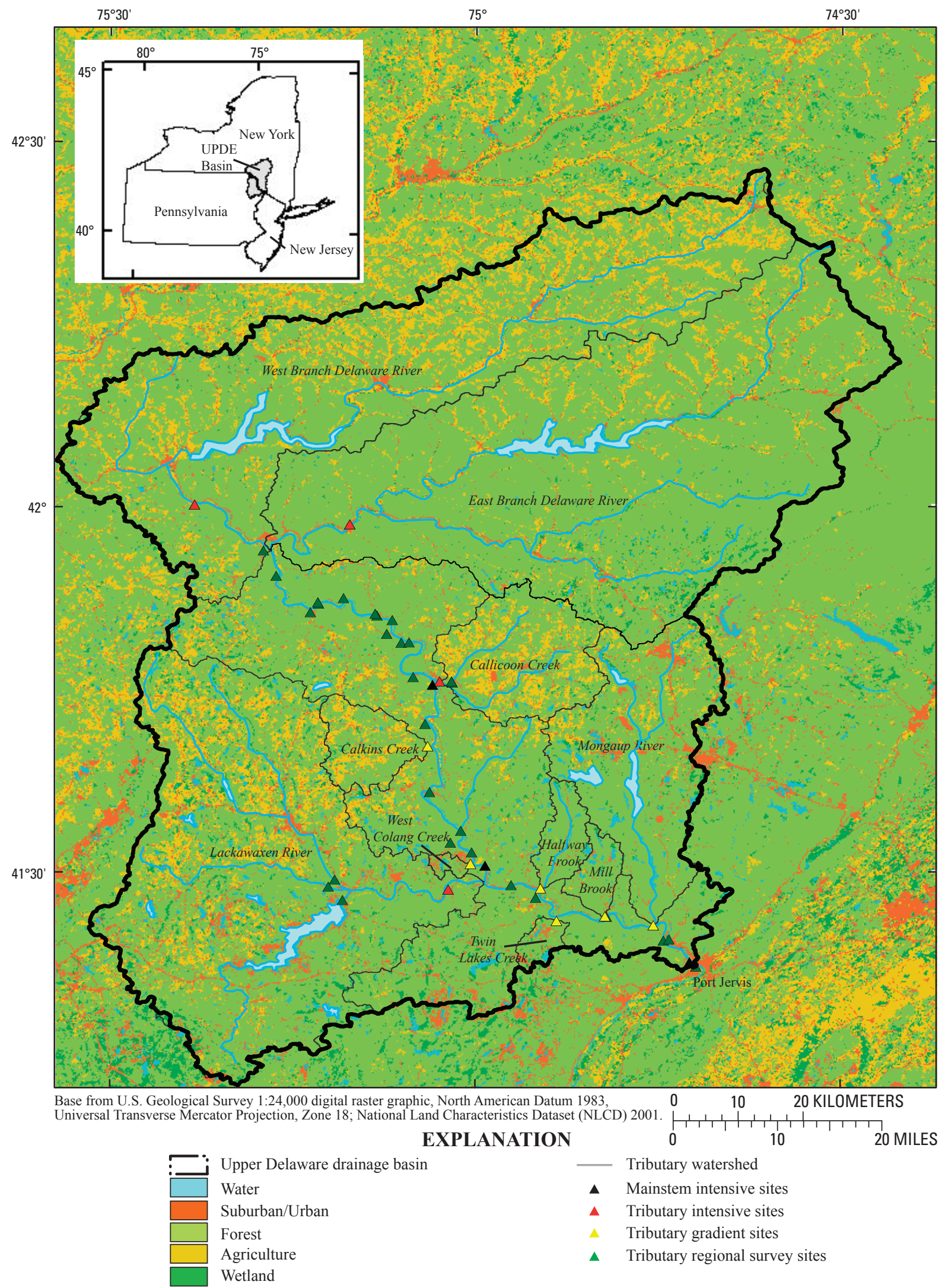

Figure 3. Map showing land use/land cover, intensive and gradient mainstem and tributary basins, and samplingsite locations in the Upper Delaware River drainage basin 
were similar to those found in other studies (Ahearn and others, 2005; Mehaffey and others, 2005). The same constituents and properties were all negatively correlated with the percentage of the basin occupied by forested land cover, but with slightly lower $\mathrm{r}^{2}$ values. These results are similar to those found by Fischer and others (2004) for the Delaware River Basin as a whole. In contrast to their results, however, in the current study no relation was found between the percentage of suburbanization and water quality. It is possible that the percentage of suburbanization in the UPDE study basins is below a critical threshold, so the forested portions of the basins are masking the effects of the current level of suburbanization.

At the gradient and intensive tributary sites, a distinct pattern was found between land use and median nutrient concentrations. Callicoon and Calkins Creeks had the highest percentages of agricultural land use in their basins (29 and 28 percent, respectively), and had the highest median nitrate and total phosphorous concentrations as well as the greatest ranges in concentration. The primarily forested basins of Mill Brook (94 percent) and Halfway Brook (95 percent) were associated with the lowest median nutrient concentrations and a much smaller range in observed concentrations during the study period. The basins with the highest percentages of suburbanization, West Colang Creek (17 percent) and Twin Lakes Creek (11 percent), were associated with median nitrate and total phosphorous concentrations and ranges similar to those of the forested basins.

\section{Water-Quality Statistics: Existing Water Quality}

Water-quality statistics for the gradient and intensive sites are given in appendix 2 and shown graphically in figure 4. Median nitrate and total phosphorous concentrations were 1.15 and $0.01 \mathrm{mg} / \mathrm{L}$, respectively, for three sites on the mainstem Delaware River; 1.27 and $0.009 \mathrm{mg} / \mathrm{L}$, respectively, for the East Branch Delaware River; 2.04 and $0.01 \mathrm{mg} / \mathrm{L}$, respectively, for the West Branch Delaware River; and 0.68 and $0.006 \mathrm{mg} / \mathrm{L}$, respectively, for eight tributaries that represented the range of land uses in the basin. The SRMP water-quality values, existing water quality, nutrient criteria, and ecoregional reference conditions are compared in table 5. Existing water quality was to be determined for specific boundary control points, with the DRBC using median values and the 95-percent confidence limits of the median for establishment of Special Protection Waters standards. In the past, reach-wide mean values of existing water quality were used to establish Special Protection Waters standards. The number of constituents and properties common to the two data sets was limited to those shown in table 5. In addition, it should be noted that these data sets were developed using samples collected at different sites and intervals using different sampling and analytical methodologies.
Median existing specific conductance and ammonium, nitrate, total nitrogen, and total suspended solids concentrations are greater than the corresponding SRMP water-quality values. The only constituent whose median concentration was less than the SRMP value was total phosphorous. Differences between existing and SRMP water-quality values are even greater if mean values are used.

\section{Water-Quality-Condition Assessment: Nutrients}

Maps of tributary and mainstem Delaware River water-quality conditions were created for nitrate and total phosphorous (figs. 5 and 6, respectively). Each basin was classified as eutrophic, mesotrophic, or oligotrophic based on the nutrient thresholds proposed by Smith and others (2006). These nutrient thresholds were based in part on data collected in wadeable streams of the UPDE Basin. These classifications are applied to the basins as a whole; it is not implied that all waters in a basin are necessarily of that classificationrather, the overall quality of waters being exported from that basin to the UPDE are of that class. Streams in which nutrient concentrations exceed the eutrophic threshold may be threatened by nutrient impairment.

To be consistent with the methods of Smith and others (2006), median nutrient values were calculated for the period April through September before comparisons to the nutrient thresholds were made. Median nutrient values for the entire year were similar to those for April through September for most sites, with the exception of nitrate concentrations at Callicoon and Calkins Creeks, which were 25 and 75 percent greater for the entire year, respectively. The nitrate condition map includes the survey sites (4 samples per site) as well as the intensive and gradient sites (13 to 68 samples per site). The total phosphorous condition map includes the intensive and gradient sites (11 to 21 samples per site). Survey sites were not included in the total phosphorous map as total phosphorous was not measured during stream surveys.

Nitrate concentrations in the East Branch and West Branch Delaware River, Delaware River at Callicoon, Delaware River at Barryville, and Callicoon Creek all exceeded the eutrophic threshold. The remaining intensive and gradient sites were classified as mesotrophic with respect to nitrate. Concentrations of total phosphorous did not exceed the eutrophic threshold at any of the sites. Callicoon Creek, Calkins Creek, the Lackawaxen River, and West Colang Creek were classified as mesotrophic with respect to total phosphorous.

With the exception of Callicoon Creek and the West Branch Delaware River, the watersheds classified as eutrophic with respect to nitrate were all greater than 87 percent forested. In these mostly forested basins, the primary concern in terms of nitrate input was the long-term effects of acid deposition. Nitric acid is known to have a major role in 

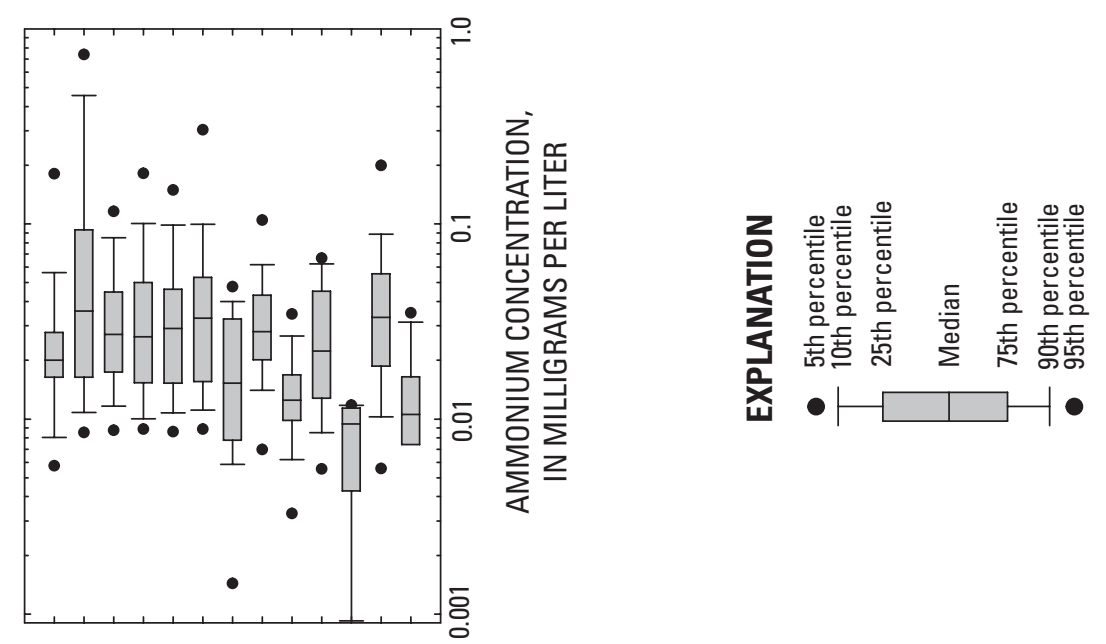

离

हो 홍

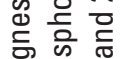

을 을 융

돈 苋 劳

ปั
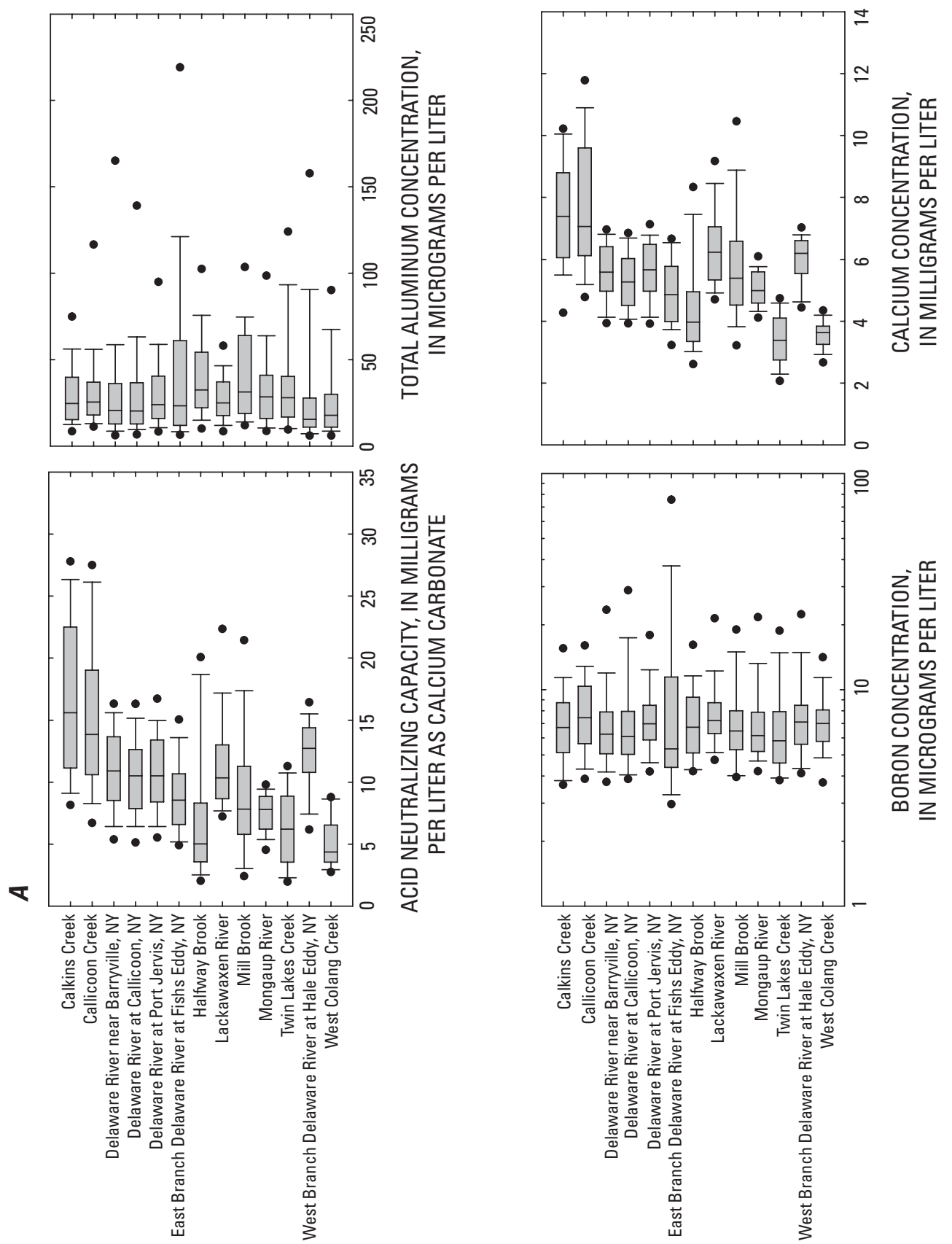

.응 힝

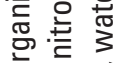

응 등

ญ 용

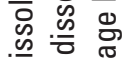

흐 $\frac{\bar{\pi}}{\pi}$

은 은 능

흗 究㟧

品告?

드 힣

哥产

ปั है

을 竞

ᄃิ क口

힝 등

ह่ ธํํㅇ

产号总

이 क

ह

हั

롣 응 응

트엄

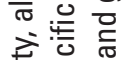

등 ญ

त्व के क

일.

产苋

즌 흥 잉

ฮ들 空

은 을 을

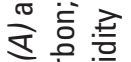

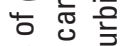

을 을 을

곤

옿 흥

.

- 包 웡

힌 ฮ

혼드 क 

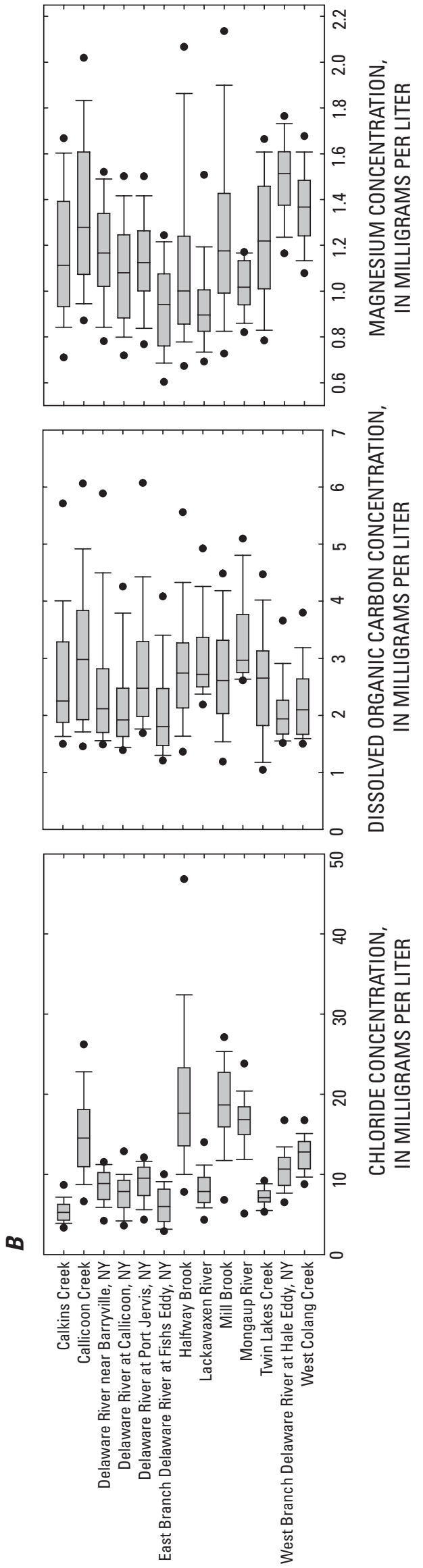

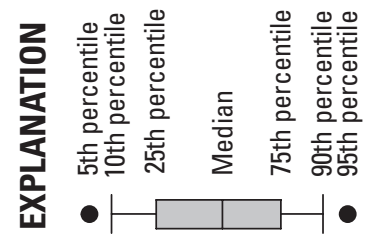

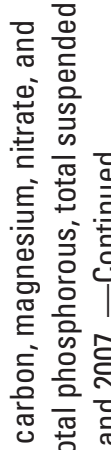

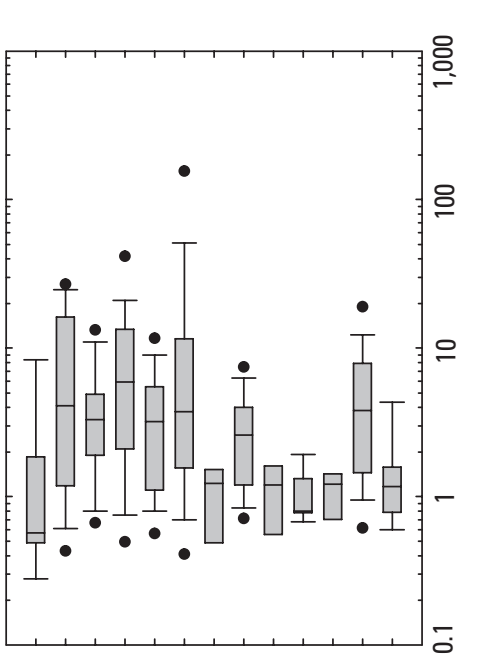

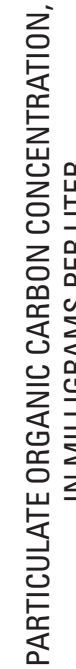

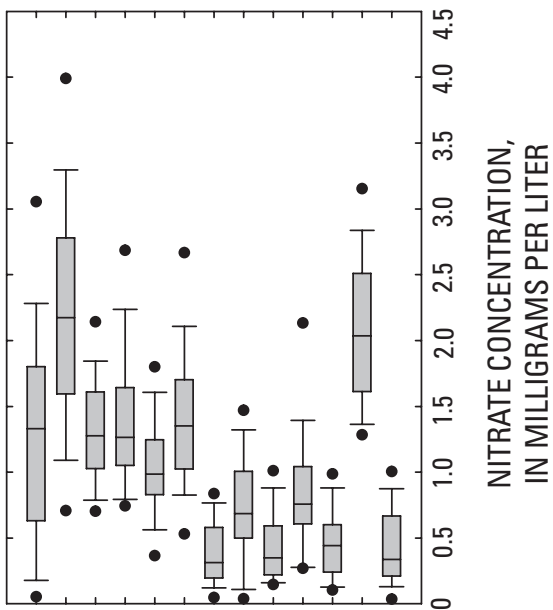

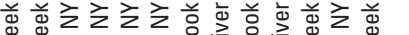

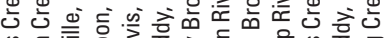

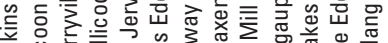

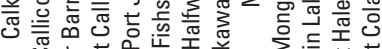

o

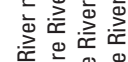

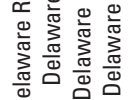

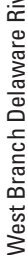

늘

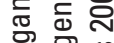

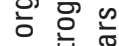

일

웡

䑶

造

음 핌

空

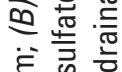

产宫㟒

정 믄

空克

站

응

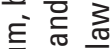

完的

总

空

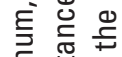

.

흠

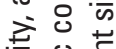

证

융

कि

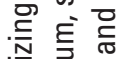

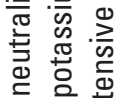

믕 퐁.

उ닝

行

结 늃

吾

密

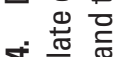

言递兽 

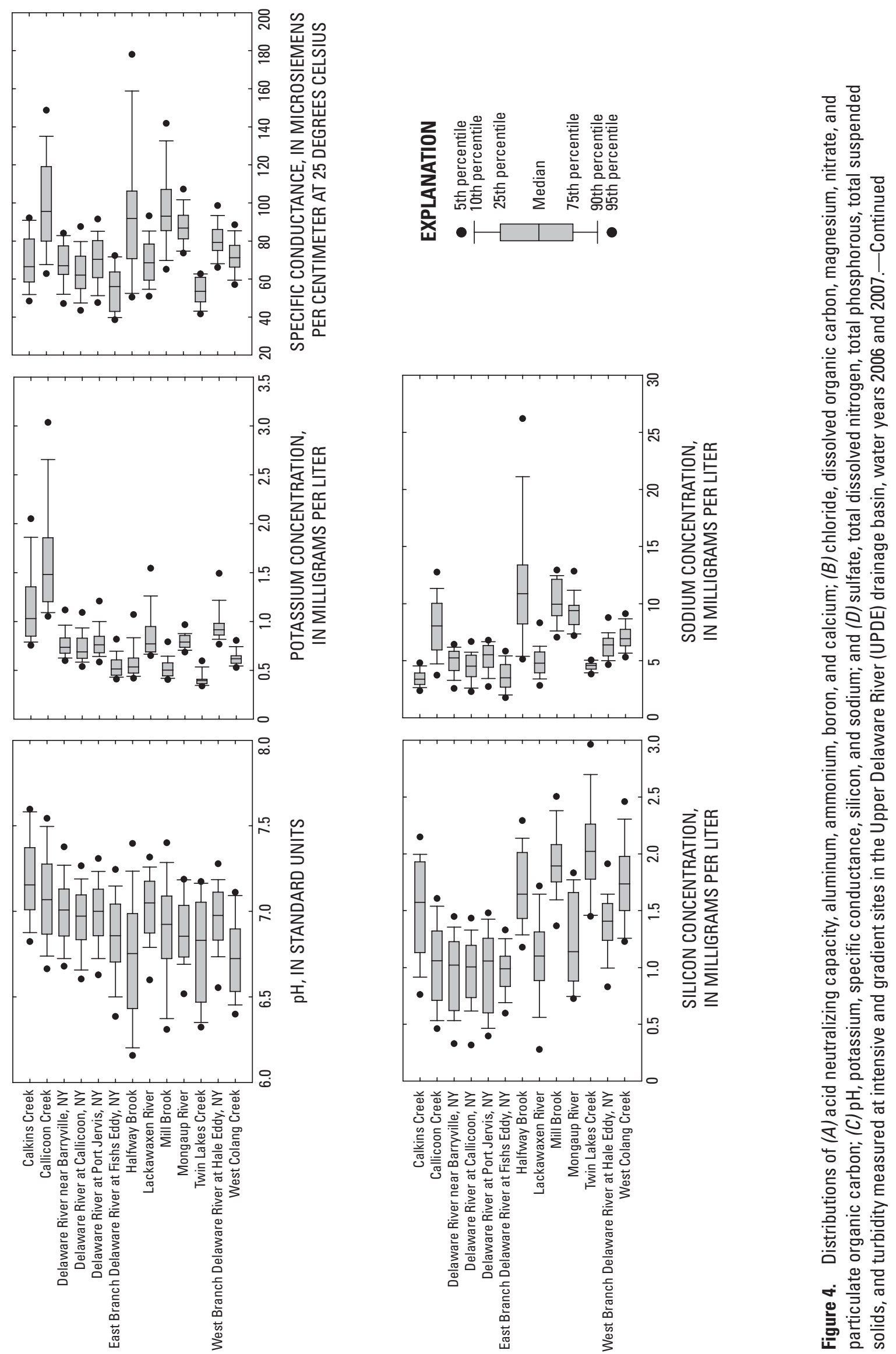

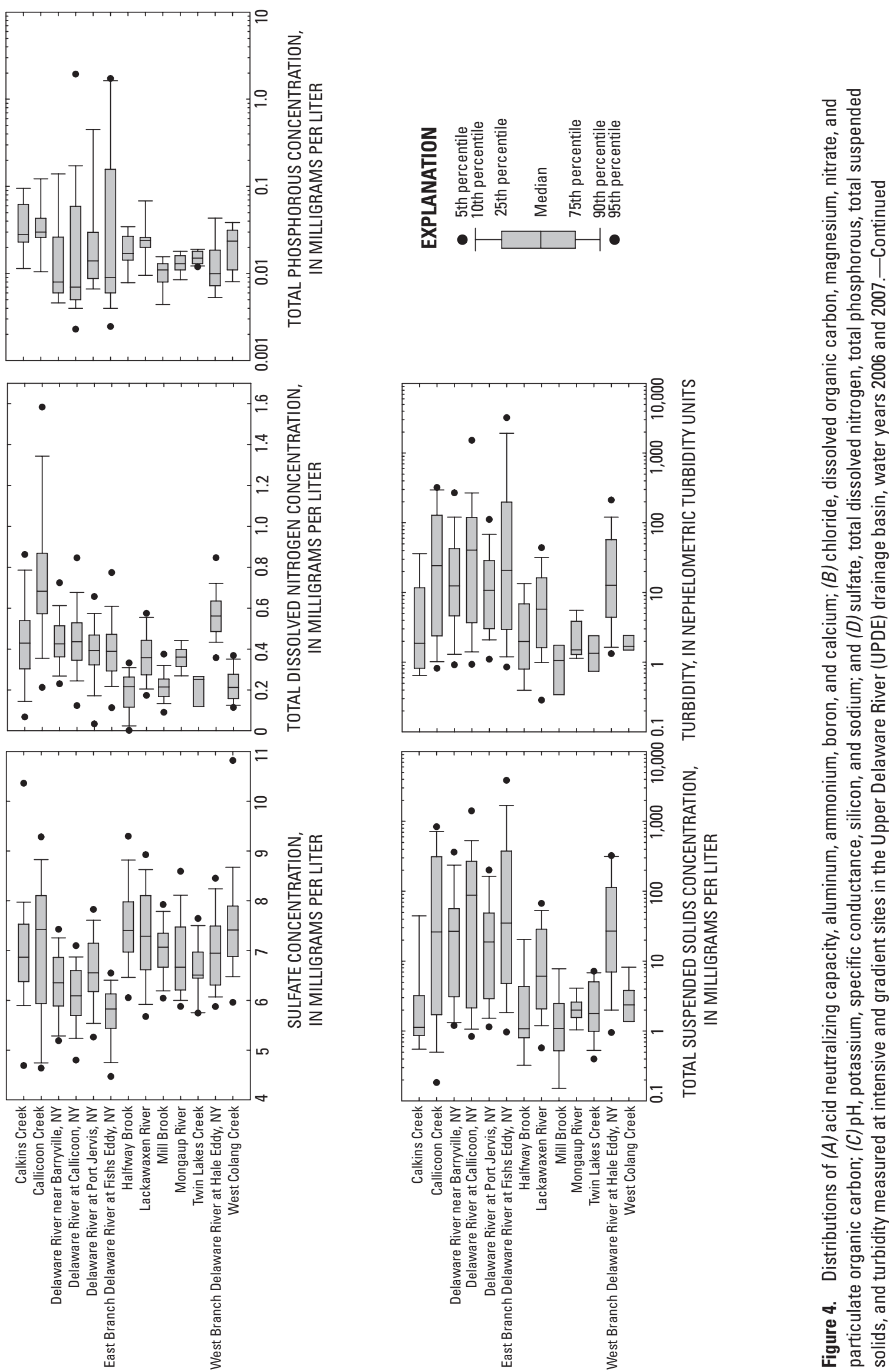
Table 5. Values of selected common constituents and properties for original Scenic Rivers Monitoring Program (SRMP) water quality (Delaware River Basin Commission, 2008b), existing main stem Delaware River water quality, nutrient criteria (Smith and others, 2006), and U.S. Environmental Protection Agency (USEPA) ecoregional reference conditions.

[mg/L, milligrams per Liter; $\mu \mathrm{S} / \mathrm{cm}$, microsiemens per centimeter in 25 degrees Celsius; NA, not available]

\begin{tabular}{lcccc}
\hline \multicolumn{1}{c}{ Constituent or property } & $\begin{array}{c}\text { SRMP } \\
\text { water quality }^{1}\end{array}$ & $\begin{array}{c}\text { Existing } \\
\text { water quality }^{2}\end{array}$ & $\begin{array}{c}\text { Nutrient } \\
\text { criteria }^{3}\end{array}$ & $\begin{array}{c}\text { USEPA ecoregional } \\
\text { reference condition }^{4}\end{array}$ \\
\hline Ammonia + ammonium $(\mathrm{mg} / \mathrm{L})$ & 0.022 & 0.028 & $\mathrm{NA}$ & $\mathrm{NA}$ \\
Conductivity $(\mu \mathrm{S} / \mathrm{cm})$ & 68 & 66.9 & $\mathrm{NA}$ & $\mathrm{NA}$ \\
Nitrate + nitrite $(\mathrm{mg} / \mathrm{L})$ & 0.293 & 1.15 & $0.24,0.98$ & 0.38 \\
Total nitrogen $(\mathrm{mg} / \mathrm{L})$ & 0.202 & 0.42 & $\mathrm{NA}$ & $\mathrm{NA}$ \\
Total phosphorous $(\mathrm{mg} / \mathrm{L})$ & 0.029 & 0.01 & $0.0175,0.065$ & 0.01 \\
Total suspended solids $(\mathrm{mg} / \mathrm{L})$ & 4 & 29 & $\mathrm{NA}$ & $\mathrm{NA}$ \\
\hline
\end{tabular}

${ }^{1}$ Mean values of original SRMP data set used for reachwide regulations.

${ }^{2}$ Median values of data collected by U.S. Geological Survey during water years 2006 and 2007 (median values are shown here because the new Special Protection Waters regulations are to be based on median values; reach-wide main stem values are shown here for comparison to SRMP values).

${ }^{3}$ Nutrient criteria of Smith and others (2006): oligotrophic-mesotrophic nutrient condition boundary, mesotrophic-eutrophic nutrient condition boundary (threatened with impairment).

${ }^{4}$ USEPA Ecoregion VIII ecoregional reference condition.

streamwater acidification, especially during spring high flow; low $\mathrm{pH}$ and $\mathrm{ANC}$ values are associated with the high nitrate levels (Murdoch and Stoddard, 1992). All of these forested basins threatened with nitrate impairment showed signs of episodic acidification during spring snowmelt: elevated levels of nitrate, low $\mathrm{pH}$, and low ANC. Spring high-flow ANC values were as much as 50 percent lower than median annual values for the intensive sites and as much as 50 to 70 percent lower than summer base-flow values for the survey sites.

Nitrate concentrations in the other eutrophic basins, as well as the mesotrophic basins, were most likely affected by both agricultural runoff and long-term acid deposition. Substantial portions of the Callicoon Creek and West Branch Delaware River Basins were in agricultural production, and median levels of nitrate, $\mathrm{ANC}$, and $\mathrm{pH}$ in these streams during the study period were higher than in the forested intensive and gradient site streams. The mainstem of the Delaware River was eutrophic with respect to nitrate from the northern boundary of the UPDE downstream to Pond Eddy, where it returned to mesotrophic status.

The basins assessed as mesotrophic with respect to total phosphorous included those with large percentages of agricultural land use as well as those with greater than 90 percent forest cover, with the exception of the East Branch Delaware River, which was classified as oligotrophic. The contribution of water from the East Branch Delaware River with low concentrations of total phosphorous kept the mainstem in an oligotrophic condition until the confluence with Callicoon Creek, where the mainstem became mesotrophic. The eutrophic threshold for total phosphorous was not exceeded in any of the basins.

Median concentrations of total dissolved nitrogen at all of the mainstem Delaware River sites as well as those on the East Branch and West Branch Delaware River, Callicoon Creek, and Calkins Creek exceeded the USEPA ecoregional reference condition. Median concentrations at all of the intensive and gradient study sites, with the exception of the East Branch Delaware River, the Delaware River at Callicoon, and the Delaware River at Barryville, exceeded the USEPA ecoregional reference condition for total phosphorous.

\section{Tiered Monitoring Strategy Water-Quality Results}

The water-quality results from the tiered monitoring strategy can be described using cumulative curves. Cumulative curves can yield valuable information about regional and sitespecific water-quality conditions. The position of the curve in relation to reference-site curves or water-quality thresholds can indicate the frequency of samples or the percentage of the basin area that exceeds these reference curves and guidelines. The shape of the curve can indicate whether the minimum or maximum values (or both) are above the level of a reference curve or threshold. By plotting curves of data, such as those 


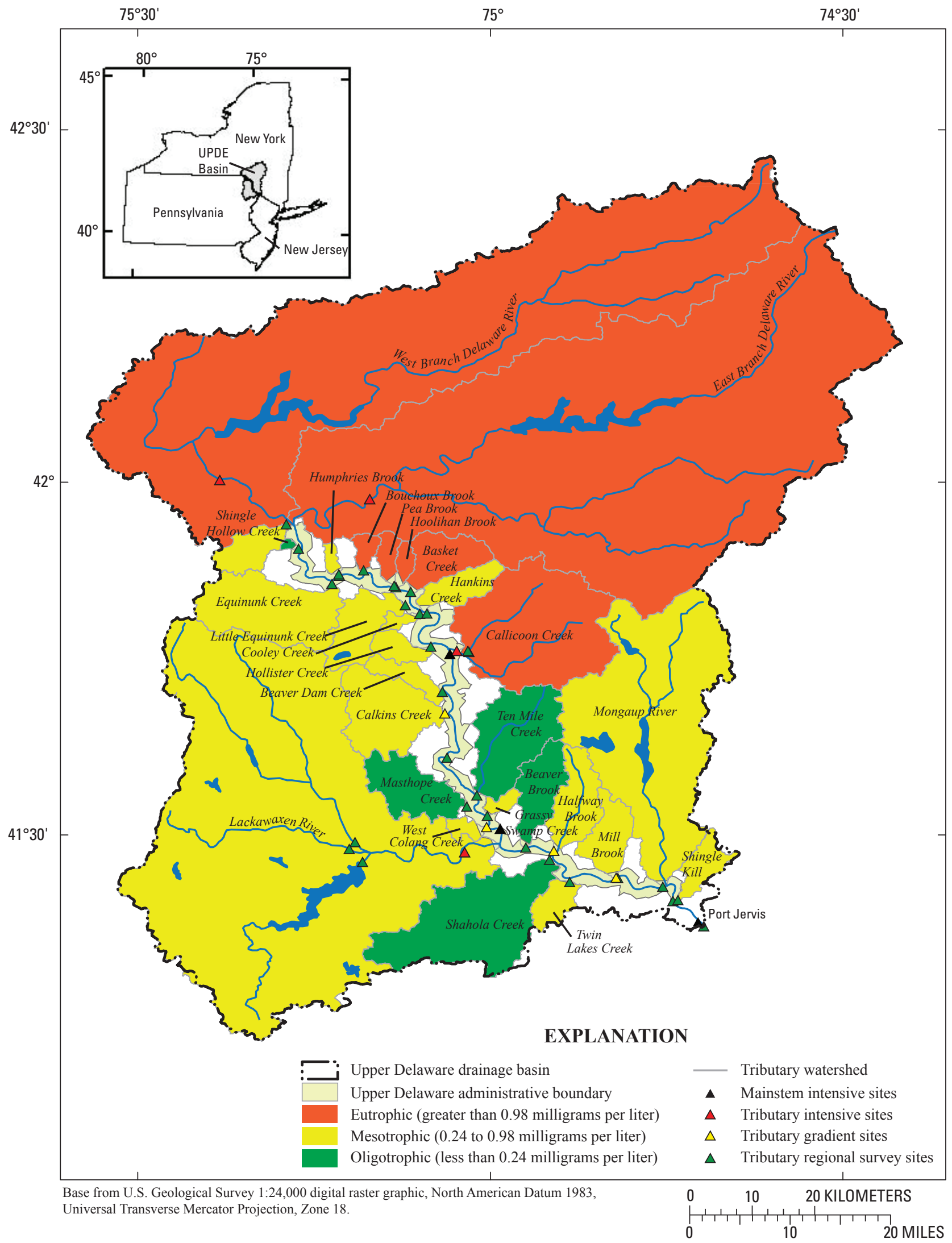

Figure 5. Classifications of water quality with respect to nitrate concentration in the Upper Delaware River (UPDE) tributary basins, water years 2006 and 2007. (Concentrations are median values at each monitoring location; classification ranges are those suggested by Smith and others, 2006; $\mathrm{mg} / \mathrm{L}$, milligrams per liter). 


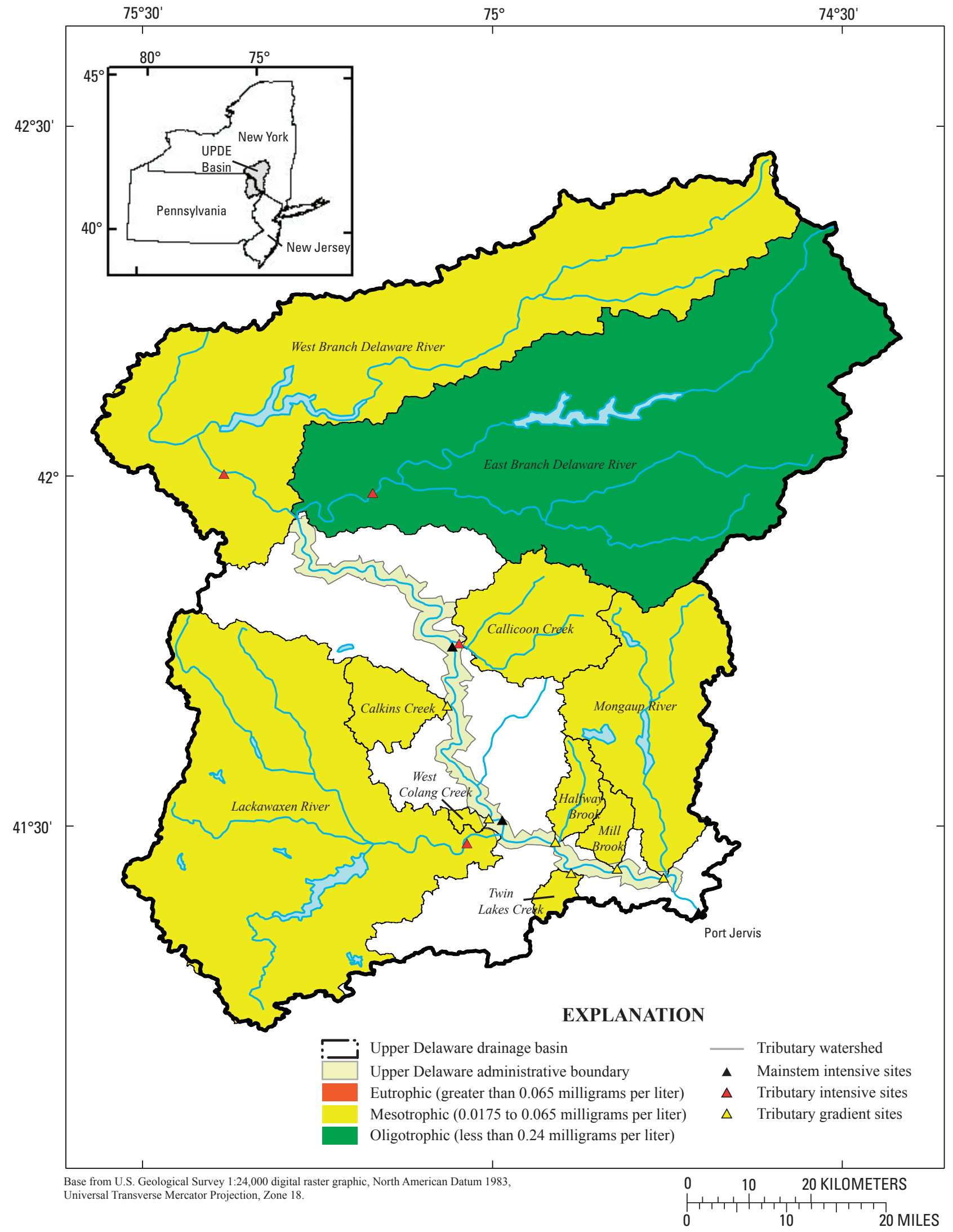

Figure 6. Classifications of water quality with respect to total phosphorous concentration in the Upper Delaware River (UPDE) tributary basins, water years 2006 and 2007. (Concentrations are median values at each monitoring location; classification ranges are those suggested by Smith and others, 2006; mg/L, milligrams per liter). 
of the seasonal stream surveys, from successive years, trends in the quality of the water in the whole population of streams over time can be identified from shifts in the curve's shape and location. Similarly, seasonal shifts can be identified by comparing plots from different seasons. If cumulative curves from different time periods are compared, improving water-quality conditions with respect to constituents such as nutrients would be indicated by a shift to the left over time, whereas a shift to the right would represent degradation of water quality. This convention is reversed for $\mathrm{pH}$ and $\mathrm{ANC}$, where a shift of the curve to the right, representing an increase in $\mathrm{pH}$ or $\mathrm{ANC}$, would be considered an improvement in water quality.

Three types of cumulative curves were created to describe the existing water-quality conditions in the UPDE: regional, site-specific, and spatial-temporal. The characteristics of these curves and their interpretations are discussed below.

\section{Regional Stream Surveys}

Stream surveys allow for the extension of data collected at intensively sampled sites to a regional scale, which is advantageous because sampling every stream in a basin is typically cost prohibitive or physically impossible. The use of probability surveys negates the bias of judgment or convenience sampling (Olsen and others, 1999). In this study, the number of tributaries was small enough that all major tributaries in the study area could be sampled during regional stream surveys.

The regional stream-survey cumulative curves describe the water-quality condition of the entire basin, and can be integrated with data from the intensively sampled sites. By plotting data from successive stream surveys, trends in the quality of water in the whole population of streams over time can be identified from shifts in the curves' shape and location. Similarly, seasonal shifts can be identified by plotting the results of surveys from different seasons.

The regional cumulative curves shown in figure 7 describe the percentage of the basin at or below different concentrations by focusing on the data collected during spring high-flow and summer base-flow surveys during the 2006 and 2007 water years. The $x$-axis shows concentration and the $y$-axis shows the cumulative percentage of the basin area in which the concentration was at or below a given value. Also shown are box plots of data collected at the gradient sites over the course of this study. The box plots for the gradient sites are plotted at the same y-axis position as the corresponding stream-survey site point.

Figure 7 allows for comparisons of results between stream surveys and shows the integration of the regional and site-specific data using nitrate concentrations as an example. By plotting the cumulative curves of the survey data and the box plots of the gradient sites together, the regional and site-specific data become more meaningful. This combination places the survey data in the context of the overall annual variability and describes how the data from the gradient sites relate to the regional data. Nitrate concentrations from both summer low-flow surveys and the spring 2006 high-flow survey tend to plot in the lower percentiles of the concentrations from the intensively sampled gradient sites, whereas the spring 2007 high-flow survey data plot in the upper percentiles, as shown by the integration of the box plots with the cumulative curves. The spacing of the box plots along the survey cumulative curves shows that the gradient sites are representative of the water-quality conditions found throughout the basin.

The plots in figure 7 show year-to-year and seasonal shifts in nitrate concentration. The results of a Wilcoxon one-sided test indicate that nitrate concentrations were greater during the 2007 spring high-flow $(\mathrm{p}=0.019)$ and summer base-flow ( $p<0.001$ ) surveys than during the 2006 spring high-flow and summer base-flow surveys, respectively, and were greater during the spring 2006 high-flow survey $(p=0.0066)$ than during the summer 2006 base-flow survey. The percentage of basin area in which the eutrophic threshold for nitrate was exceeded was approximately 55 percent during the 2006 spring high-flow survey and approximately 65 percent during the 2007 spring high-flow survey. The regional curves describe the overall quality of water in the basin and could be used as a management tool to determine whether it is improving or degrading over time. This regional analysis would not be possible with a monitoring strategy in which water-quality data are collected at only a modest number of fixed sites and, without the data from the intensively sampled sites, the temporal context of the surveys would be lost.

\section{Gradient and Intensive Site Networks}

Cumulative curves describing the water-quality results for the gradient and intensive sites were created for five common constituents and properties of interest: $\mathrm{pH}$, nitrate, specific conductance, total phosphorous, and total suspended solids. Each of these cumulative plots is shown with waterquality thresholds (Smith and others, 2006) and curves representing conditions at reference sites and gradient sites for comparison. The reference sites chosen were those intensive and gradient sites with drainage basins that had greater than 80 percent forest cover, less than 8 percent suburbanization, and median specific-conductance values less than $150 \mu \mathrm{S} / \mathrm{cm}$ (Smith and others, in press).

The cumulative curves in figure 8 were plotted by combining the data from gradient and intensive sites within each land-use class. Because the reference curves were created using the data from the forested sites, the reference-site and forested-site curves are identical. These plots show the effects of land use on water quality, which land use is most frequently associated with exceedance of water-quality thresholds, and the relation of different land uses to reference curves. These plots demonstrate which land use has the greatest potential 

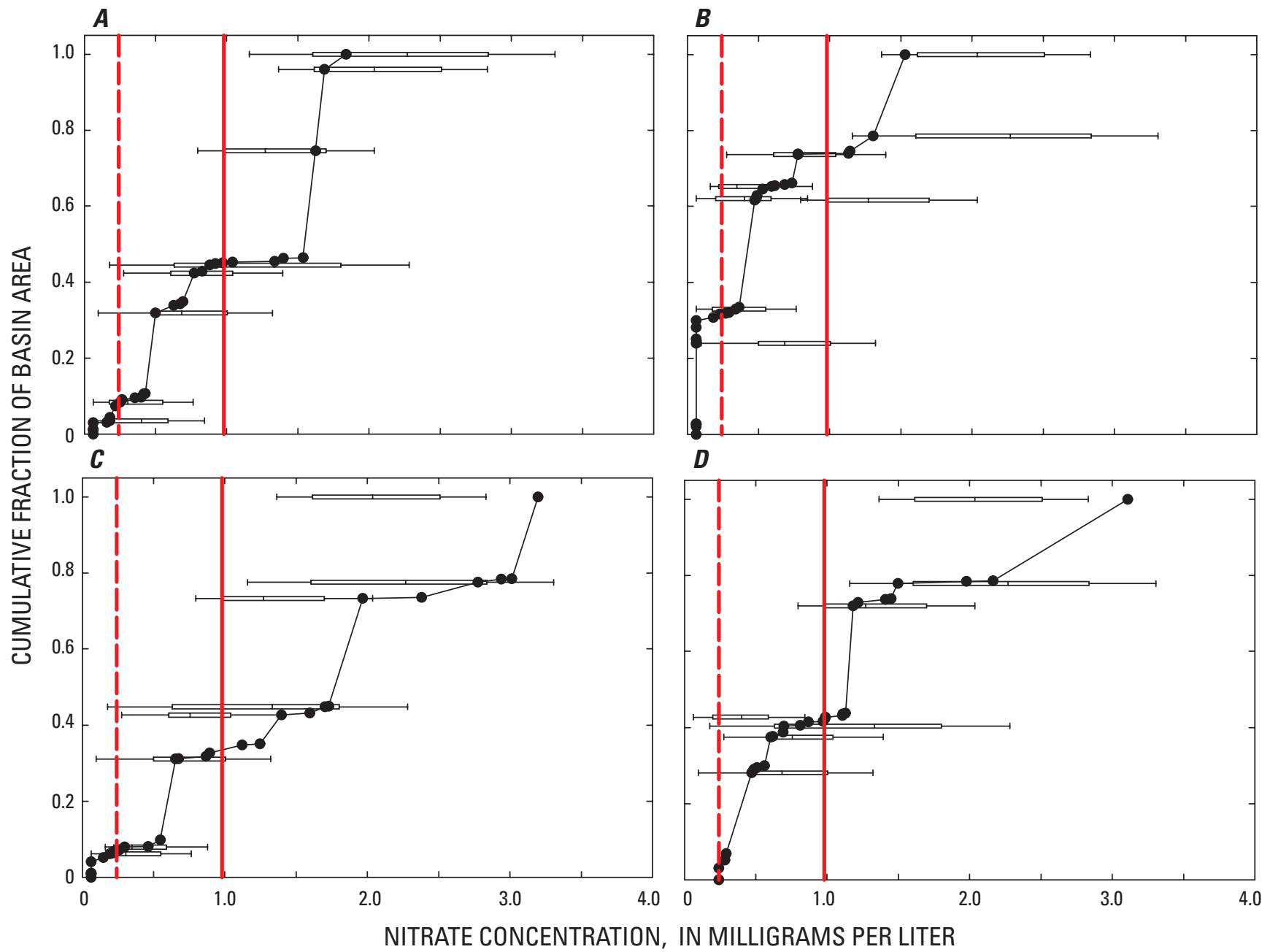

EXPLANATION

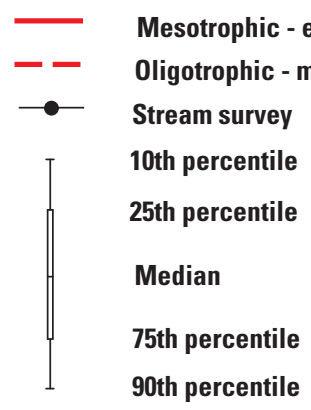

Figure 7. Regional cumulative curves of basin area ranked by increasing nitrate concentration for $(A)$ spring 2006 high flow, (B) summer 2006 base flow, (C) spring 2007 high flow, and (D) summer 2007 base flow with box plots for selected gradient sites for the Upper Delaware River (UPDE) tributaries. (Trophic boundaries from Smith and others, 2006.) 

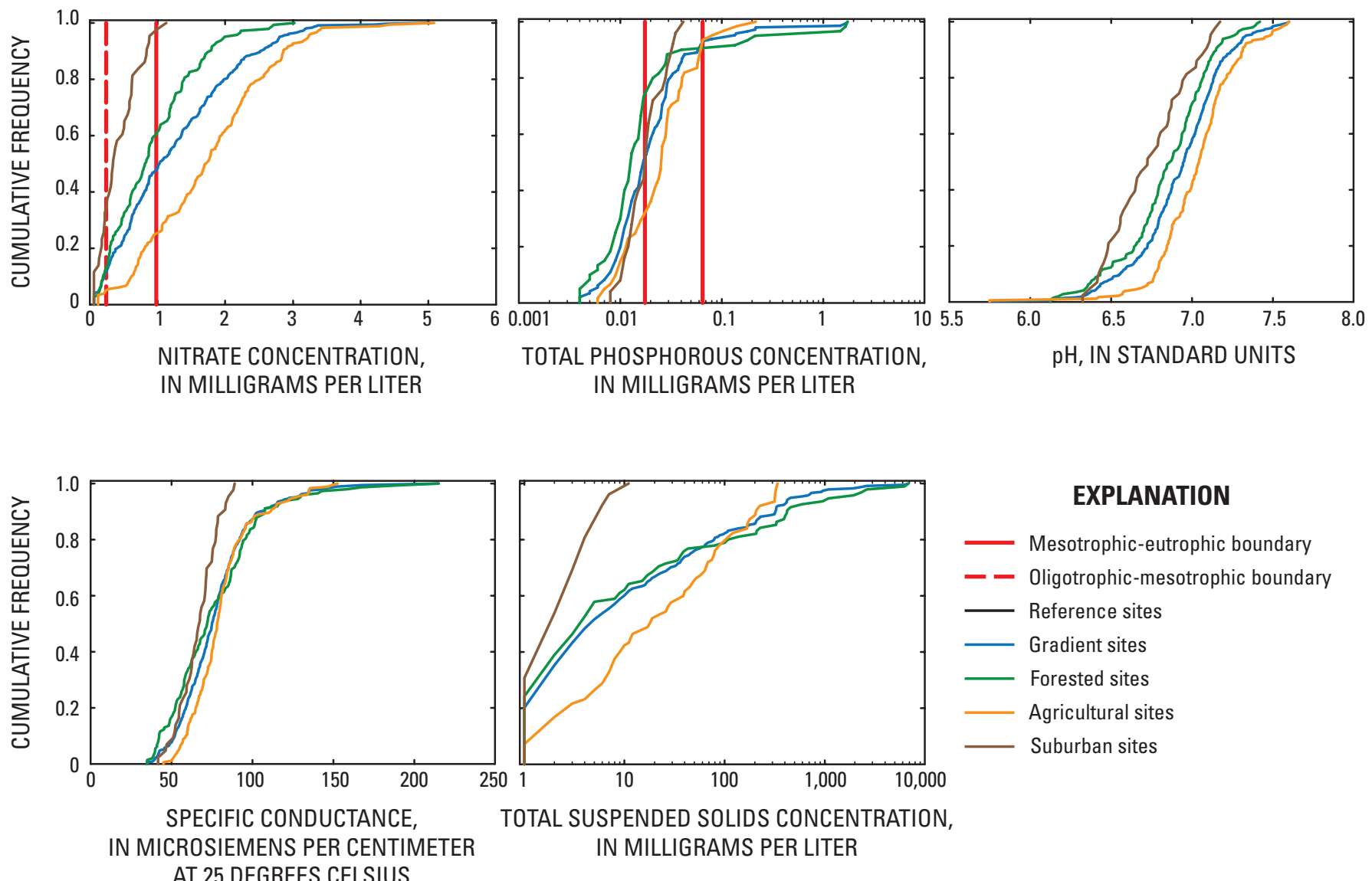

\section{EXPLANATION}

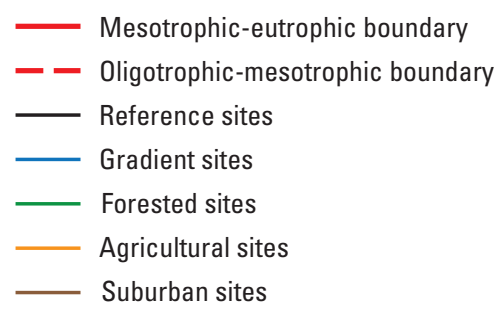

Figure 8. Cumulative frequency curves of nitrate concentration, total phosphorous concentration, pH, specific conductance, and total suspended solids concentration for different land uses in the Upper Delaware River (UPDE) drainage basin. (Trophic boundaries from Smith and others, 2006; drainage basins of reference sites are greater than 80 percent forested and less than 8 percent suburbanized, and have associated specific-conductance values less than 150 microsiemens per centimeter; gradient sites represent the range of land uses found in the basin.)

to degrade water quality. For example, nitrate concentrations in 75 percent of the samples from agricultural sites were higher than the nitrate eutrophic threshold, whereas those in 40 percent of the samples from forested sites were above this threshold. Therefore, with respect to nitrate, the primary concern for potential impairment of water quality in the UPDE is agricultural runoff; a secondary concern is the longterm effects of acid deposition in forested basins. Values of $\mathrm{pH}$ and total suspended solids concentrations were higher at agricultural sites than at sites in other land uses and the reference sites.

Site-specific cumulative curves for gradient and intensive sites grouped by land use are shown in figures 9 to 11 . The site-specific plots display the frequency of occurrence of samples in which concentrations exceed water-quality thresholds and reference curves. Figure 9 shows that more than 90 percent of the samples collected at both Callicoon Creek and West Branch Delaware River exceeded the water-quality threshold for nitrate and were approximately
$1 \mathrm{mg} / \mathrm{L}$ higher than the reference curve for most cumulative frequencies. The total phosphorous threshold was exceeded in 0 to 10 percent of the samples from the agricultural sites. Total suspended solids concentrations were highest in samples from Callicoon Creek and West Branch Delaware River for most cumulative frequencies. $\mathrm{pH}$ was higher than the reference curve for most cumulative frequencies at all of the agricultural sites. Callicoon Creek was the only agricultural site at which specific conductance was consistently higher than the reference curve (fig. 9).

Nitrate concentrations in 75 percent of the samples from the East Branch Delaware River were greater than the nitrate threshold for eutrophic impairment (fig. 10). It is apparent from figure 10 that the water-quality signature at the East Branch Delaware River was different from those at the sites in the smaller forested basins (Halfway Brook, Mill Brook, and Mongaup River); concentrations of nitrate, total phosphorous, and total suspended solids at the East Branch Delaware River were generally higher for most cumulative frequencies, 

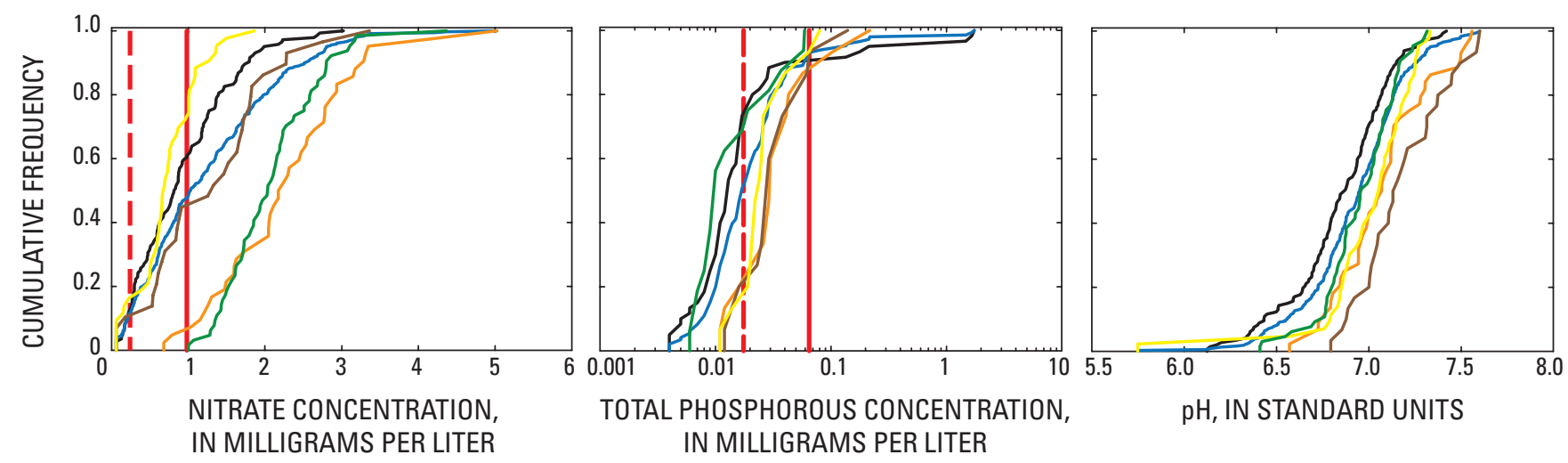

IN MILLIGRAMS PER LITER
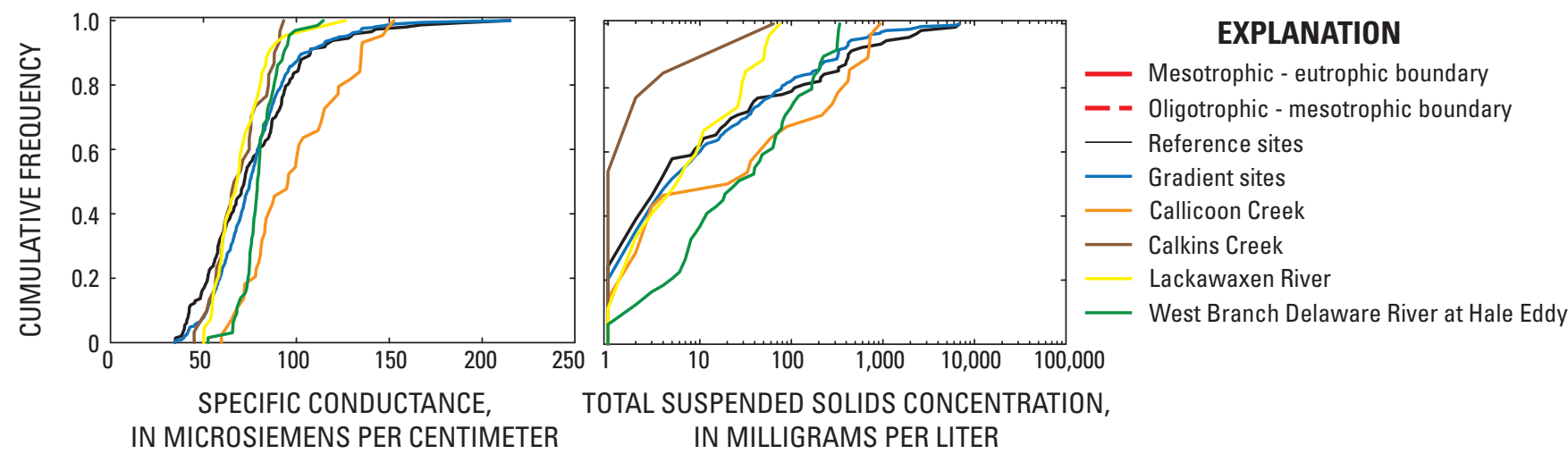

Figure 9. Site-specific cumulative frequency curves of nitrate concentration, total phosphorous concentration, $\mathrm{pH}$, specific conductance, and total suspended solids concentration for agricultural sites in the Upper Delaware River (UPDE) drainage basin. (Trophic boundaries from Smith and others, 2006; drainage basins of reference sites are greater than 80 percent forested and less than 8 percent suburbanized, and have associated specific-conductance values less than 150 microsiemens per centimeter; gradient sites represent the range of land uses found in the basin.)

whereas specific conductance was generally lower (fig. 10). This finding could be the result of the difference in drainagebasin size, the presence of pockets of agriculture and small towns in the basin, and (or) the extreme storm events that occurred during the study period.

Of the samples from West Colang Creek and Twin Lakes Creek, less than 5 percent contained nitrate or total phosphorous at concentrations that exceeded the eutrophic threshold, and none had values for nitrate, $\mathrm{pH}$, specific conductance, or total suspended solids that exceeded those at the reference sites (fig. 11). As previously mentioned, it is possible that the basins draining to these sites have not reached a critical threshold of suburbanization at which water-quality degradation would become apparent. Total phosphorous concentrations at West Colang Creek and Twin Lakes Creek, however, were slightly greater than most of the concentrations on the total phosphorous reference curve at equal cumulative frequencies.

An example of a spatial-temporal cumulative curve for nitrate and total phosphorous is shown in figure 12 .
This cumulative curve is based on a method modified from the Chesapeake Bay Program (Chesapeake Bay Program Scientific, Technical and Advisory Committee, 2006). This cumulative curve depicts the frequency at which the nitrate and total phosphorous thresholds for impairment were exceeded for given percentages of the UPDE Basin. The curve was created by calculating the percentage of the basin in which concentrations were greater than the eutrophic threshold for each monthly gradient-site sampling trip during the study period. These spatial percentages were then ranked from largest to smallest, and the cumulative frequency of each was plotted. A spatial-temporal curve depicting highquality waters would plot along the $y$-axis, passing very close to the origin, and then along the x-axis (fig. 12). This ideal curve could be changed to depict desired conditions by adjusting the relation between the desired percentage of basin area and the corresponding percentage of time during which samples contained concentrations less than the eutrophic threshold. The plot in figure 12 shows that nitrate concentrations in 60 percent of the basin were greater than the 

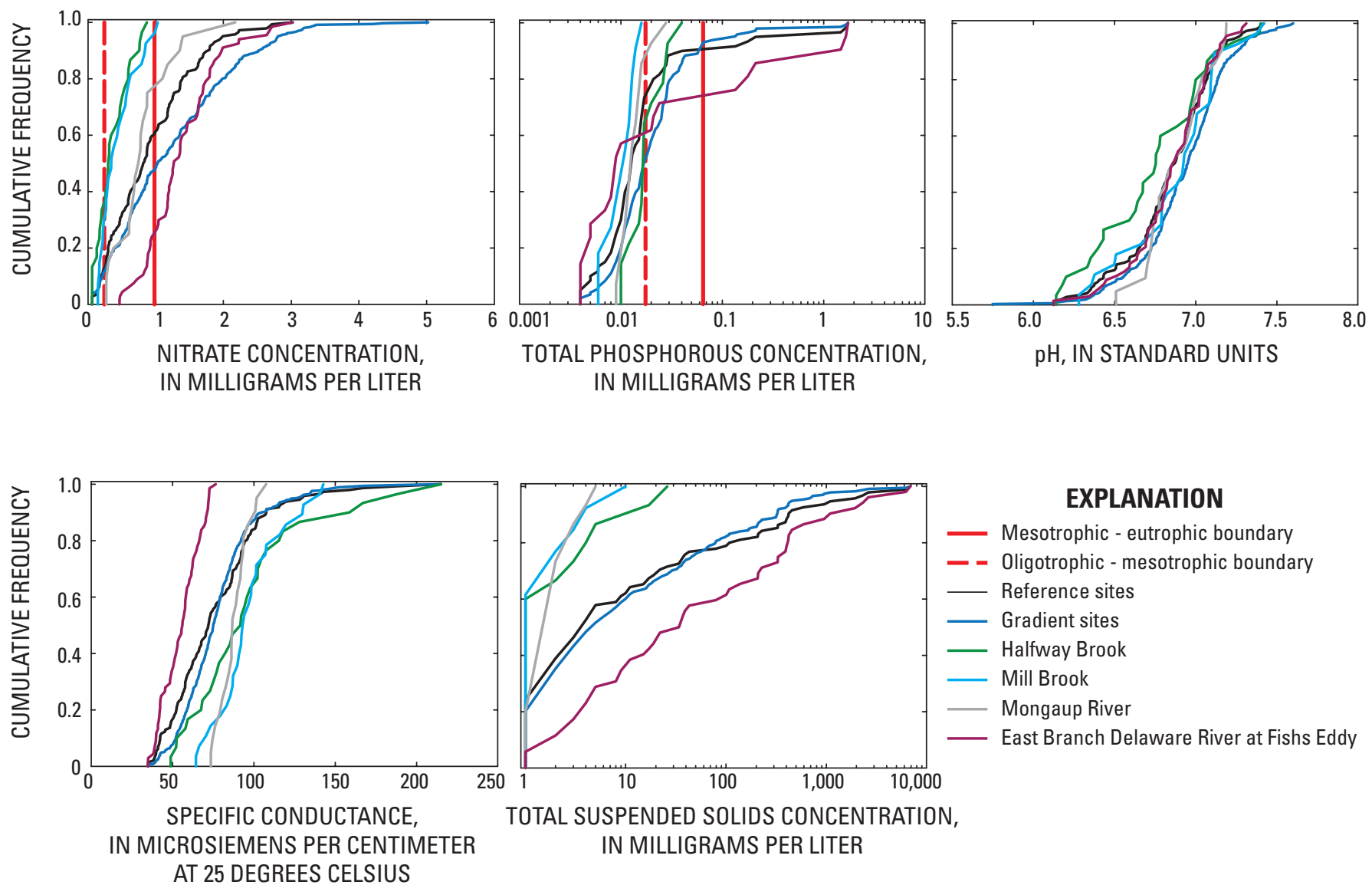

Figure 10. Site-specific cumulative frequency curves of nitrate concentration, total phosphorous concentration, pH, specific conductance, and total suspended solids concentration for forested sites in the Upper Delaware River (UPDE) drainage basin. (Trophic boundaries from Smith and others, 2006; drainage basins of reference sites are greater than 80 percent forested and less than 8 percent suburbanized, and have associated specific-conductance values less than 150 microsiemens per centimeter; gradient sites represent the range of land uses found in the basin.)

nitrate water-quality threshold approximately 50 percent of the time. Improving water quality would be indicated by the curve shifting closer to the origin (Chesapeake Bay Program Scientific, Technical and Advisory Committee, 2006). The spatial-temporal cumulative curve can be used as a tool for maintaining or improving water-quality conditions while acknowledging the likelihood that 100 percent of the basin will not be at reference conditions or below water-quality thresholds 100 percent of the time.

Continued use of the tiered monitoring strategy in the future with sampling conducted year round would allow for robust future assessments of water quality and detection of changes in water quality over time. Sampling year round is important, as sampling only during the growing season does not capture the spring snowmelt runoff or the highflow storm events that occur during the late fall and winter months. Stormflow sampling is also important, as storm events typically move large quantities of sediment, and may contain high concentrations and result in large yields of nutrients and major ions. For example, the plots of particulate organic carbon, total suspended solids, and turbidity shown in figure 4 indicate that the median and maximum values were higher at the intensive sites, where samples were collected during storms, than at the sites that were only sampled monthly. The results of a Wilcoxon statistical test (Helsel and Hirsch, 1992) show that the results obtained by sampling only during the growing season can be different for some constituents (aluminum, nitrate, silicon, total dissolved nitrogen) than those obtained with the strategy used in this study. For example, the median concentration of total suspended solids at Callicoon Creek was $27 \mathrm{mg} / \mathrm{L}$ if sampling was conducted throughout the year and during storms, and $2 \mathrm{mg} / \mathrm{L}$ if sampling was conducted only during the growing season. Similar results were found for other sites and constiuents.

Intensive monitoring at the upper and lower bounds of the UPDE, one or two intermediate sites along the mainstem of the Delaware River between the upper and lower bounds, and key tributaries such as the Lackawaxen River and Callicoon Creek would allow for detection of changes in concentration-discharge relations as well as capture peak 

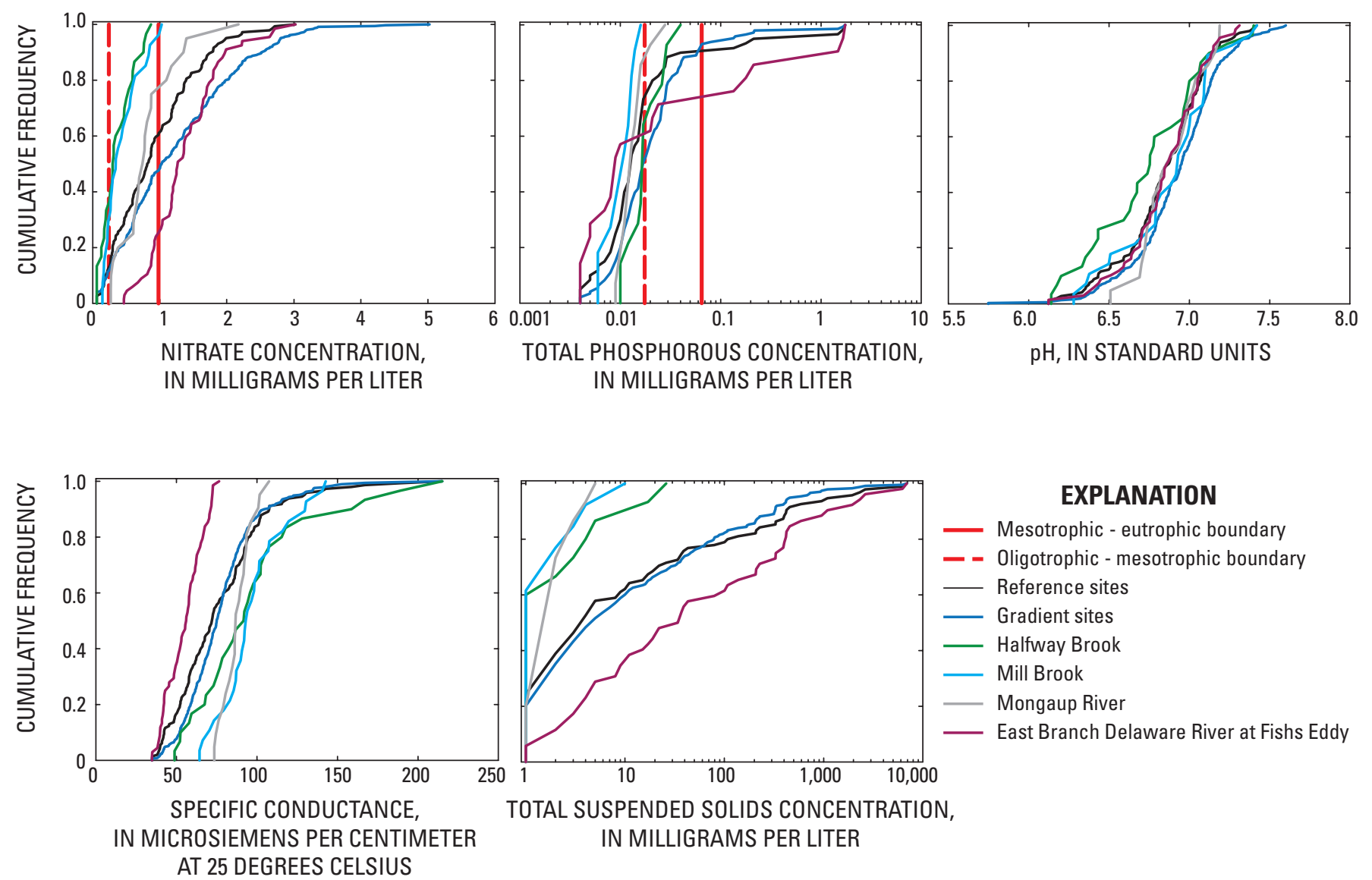

Figure 11. Site-specific cumulative frequency curves of nitrate concentration, total phosphorous concentration, $\mathrm{pH}$, specific conductance, and total suspended solids concentration for suburbanized sites in the Upper Delaware River (UPDE) drainage basin. (Trophic boundaries from Smith and others, 2006; drainage basins of reference sites are greater than 80 percent forested and less than 8 percent suburbanized, and have associated specific-conductance values less than 150 microsiemens per centimeter; gradient sites represent the range of land uses found in the basin.)

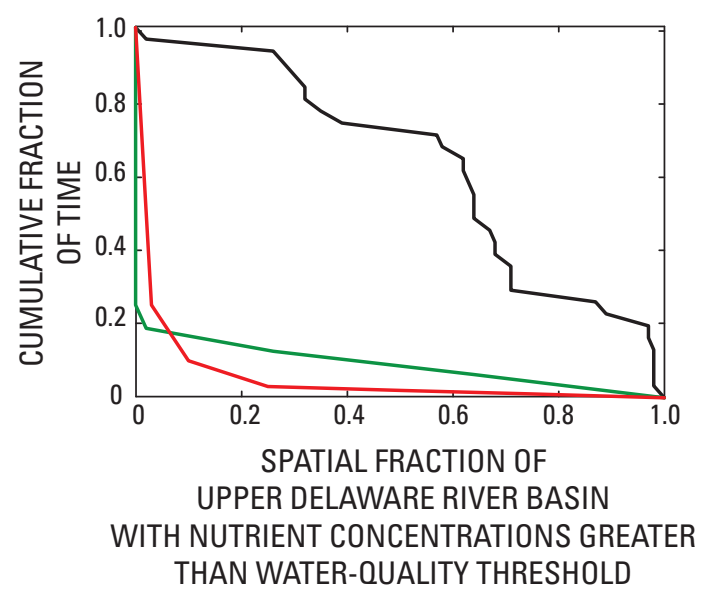

\section{EXPLANATION}

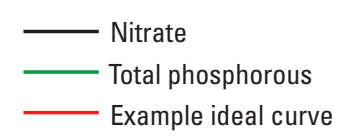

Figure 12. Spatial-temporal cumulative curves for nitrate and total phosphorous concentrations in the Upper Delaware River (UPDE) drainage basin and an example theorized ideal curve. 
concentrations during high flows. A Kruskal-Wallis test (Helsel and Hirsch, 1992) applied to the mainstem data (Delaware River at Callicoon, Delaware River near Barryville, and Delaware River at Port Jervis) showed a significant difference $(\mathrm{p}<0.05)$ in median values for some constituents and properties (chloride, dissolved organic carbon, nitrate, specific conductance, sodium, sulfate, total dissolved nitrogen, total suspended solids, and turbidity) between sites; therefore, maintaining at least one of the intermediate sites would allow for tracking changes in mainstem water quality.

Sampling at gradient study sites that represent a range of land uses would allow for water-quality monitoring at additional sites without incurring the cost of maintaining the intensive sites and would allow water-quality/land-use relations to be monitored. Continuing to monitor at the monthly sites used in this study would allow for building upon the existing data set. If results of future stream surveys show substantial changes in concentrations at certain sites or if remote sensing of land use shows changes in basin characteristics, changing the location of some of the gradient sites could be considered.

Annual high-flow and low-flow stream surveys allow for an assessment of the basin as a whole, and, when combined with the intensive-site and gradient-site data, improve the understanding of the ecosystem and allow science-based management decisions to be made. Sampling rotating groups of randomly selected tributaries such that the entire population of streams is sampled every 3 years would reduce the cost of individual surveys while still yielding unbiased results that could be extrapolated across the entire basin.

\section{Chemical and Total Suspended Solids Yields}

Annual yields for the dissolved analytes sampled during the 2006 and 2007 water years are listed in appendix 3. Yields for total suspended solids are given only for water year 2007; during water year 2006, total suspended solids were measured only during storm events.

The regional flood of June 2006 moved large quantities of both particulate and dissolved constituents through the UPDE. The East Branch and West Branch Delaware River delivered an estimated minimum of 2,214 kg/ha $(449,000 \mathrm{Mg})$ and $144 \mathrm{~kg} / \mathrm{ha}(22,200 \mathrm{Mg})$ of total suspended solids to the Delaware River, respectively. More than $874 \mathrm{~kg} / \mathrm{ha}$ (696,000 Mg) of total suspended solids were exported from the UPDE Basin during this flood event. (These estimates are minimums because of incomplete sampling over the entire storm hydrograph.) Sampling for total suspended solids prior to the flood was inadequate to determine the percentage of the annual load contributed by this storm.

The flash flood that occurred in the headwaters of the East Branch Delaware River in June 2007 contributed $27,000 \mathrm{Mg}$ of total suspended solids, $816 \mathrm{Mg}$ of particulate organic carbon, $9.98 \mathrm{Mg}$ of total phosphorous, and $30.8 \mathrm{Mg}$ of nitrate to the Delaware River. The difference in loads at the East Branch site and the Delaware River at Callicoon site indicates $11,100 \mathrm{Mg}$ of solids were deposited in the river between the East Branch site and the Delaware River at Callicoon site by the time 95 percent of the stormflow had passed the Delaware River at Callicoon site. These sediments are likely to be re-suspended by future stormflows.

Nitrate yields at most of the intensive sites were higher during water year 2007 than during water year 2006, whereas yields of major ions, dissolved organic carbon, sulfate, and aluminum were all lower during water year 2007 than during water year 2006. A comparison of yields between the East Branch and West Branch Delaware River showed that the West Branch had higher yields of nitrate, major ions, and sulfate during both water years 2006 and 2007. Yields of nitrate, major ions, and sulfate along the mainstem of the Delaware River tended to increase downstream between Callicoon and Barryville, then decrease between Barryville and Port Jervis. Yields of dissolved organic carbon increased and yields of total suspended solids decreased from Callicoon to Barryville and from Barryville to Port Jervis.

Yields of nitrate, major ions, sulfate, dissolved organic carbon, and total suspended solids at Callicoon Creek, in an agricultural watershed, were nearly twice those at the other intensive sites during water year 2006. Yields of all these constituents and properties were lower during water year 2007 at Callicoon Creek, but were higher than those at any other intensive site.

\section{Summary}

Water-quality samples were collected from the Upper Delaware Scenic and Recreational River and its tributaries during water years 2006 and 2007 to document existing water quality, determine relations between land use and water quality, and identify areas of water-quality concern. A tiered water-quality monitoring framework was used in this study, with the tiers consisting of intensively sampled sites, gradient sites representing the range of land uses present in the basin, and regional stream-survey sites.

The percentage of agricultural land use in a basin was found to be positively correlated with ANC and concentrations of calcium, potassium, nitrate, total dissolved nitrogen, and dissolved phosphorous. Streams in agricultural basins had the highest median concentrations, greatest ranges, and largest yields of nutrients. No correlations were found between suburbanization and water quality. It is possible that the level of suburbanization in the UPDE has not yet reached a critical threshold, beyond which degradation of water quality would be observed.

Maps showing water-quality classifications with respect to nutrients indicate that a large portion of the UPDE Basin ranged from mesotrophic to eutrophic with respect to nitrate. 
Nitrate concentrations in samples from the mainstem Delaware River exceeded the threshold for potential impairment with respect to nitrate from Hancock downstream to Pond Eddy. All of the intensive and gradient study sites were mesotrophic with respect to total phosphorous, with the exception of the East Branch Delaware River and the mainstem of the Delaware River from Hancock to Callicoon, which were oligotrophic.

Cumulative curves for the UPDE yielded valuable information about regional and site-specific water quality that would not have been available if the monitoring program had been limited to sampling of boundary control points only. The position of the curves in relation to reference-site curves or water-quality thresholds indicated the frequency of occurrence of samples or the percentage of basin area in which the value indicated by these curves or thresholds was exceeded. The regional cumulative curves indicated that 55 to 65 percent of the basin was beyond the eutrophic threshold in terms of nitrate during the spring high-flow surveys, and 25 to 60 percent of the basin was beyond the eutrophic threshold in terms of nitrate during the summer base-flow surveys. Land-use cumulative curves indicated that nitrate concentrations in 75 percent of samples from agricultural basins and 40 percent of samples from forested basins exceeded the eutrophic threshold for nitrate. The sitespecific cumulative curves indicated that nitrate concentrations in more than 90 percent of samples from Callicoon Creek and the West Branch Delaware River, both in basins with high percentages of agricultural land use, exceeded the eutrophic threshold for nitrate. The cumulative curves of existing water quality presented in this report can be used as a benchmark with which future cumulative curves can be compared in order to determine whether the water quality of the UPDE is improving, static, or degrading.

The tiered monitoring approach used in this study met the study objective of assessing the existing quality of water in the tributaries to and mainstem of the UPDE. This monitoring approach allowed the integration of sitespecific data with regional data, improving the understanding of the ecosystem and providing a basis for science-based management decisions.

\section{Acknowledgments}

The authors thank Don Hamilton and Jamie Meyer of the NPS Resource Monitoring Staff of the UPDE for their assistance with field work and the valuable knowledge of the UPDE they provided, and the staff at the USGS laboratory in Troy, NY, for chemical analyses.

\section{References Cited}

Ahearn, D.S., Sheibley, R.W., Dalgren, R.A., Anderson, M., Johnson, J., and Tate, K.W., 2005, Land use and land cover influence on water quality in the last free flowing river draining the western Sierra Nevada, California: Journal of Hydrology, v. 313, p. 234-247.

Bode, R.W., Novak, M.A., Abele, L.E., Heitzman, D.L., and Smith, A.J., 2004, 30 year trends in water quality of rivers and streams in New York State based on macroinvertebrate data 1972-2002: Albany, N.Y., New York State Department of Environmental Conservation, 384 p.

Bode, R.W., Novak, M.A., Abele, L.E., Heitzman, D.L., and Smith, A.J., 2006, West Branch Delaware River biological assessment: Albany, N.Y., New York State Department of Environmental Conservation, 49 p.

Bolgrien, D.W., Angradi, T.R., Schweiger, E.W., and Kelly, J.R., 2005, Contemplating the assessment of great river ecosystems: Environmental Monitoring and Assessment, v. 103 , p. 5-20.

Burns, D.A., Klaus, J., and McHale, M.R., 2007, Recent climatic trends and implications for water resources in the Catskill Mountain region, New York, USA: Journal of Hydrology, v. 336, p. 155-170.

Burns, D.A., McHale, M.R., Driscoll, C.T., and Roy, K.M., 2006, Response of surface water chemistry to reduced levels of acid precipitation: Comparison of trends in two regions of New York, USA: Hydrological Processes, v. 20, p. 1611-1627.

Chesapeake Bay Program Scientific, Technical and Advisory Committee, 2006, The cumulative frequency diagram method for determining water quality attainment: Edgewater, Md., Chesapeake Bay Program Publication 06-003, $75 \mathrm{p}$.

Conference of Upper Delaware Townships, 1986, Final river management plan for the Upper Delaware Scenic and Recreational River: Conference of Upper Delaware Townships, $197 \mathrm{p}$.

Delaware River Basin Commission, 2004, 2004 Delaware River and Bay integrated list water quality assessment: West Trenton, N.J., Delaware River Basin Commission, $96 \mathrm{p}$.

Delaware River Basin Commission, 2008a, Special Protection Waters - "Keeping the clean water clean": West Trenton, N.J., Delaware River Basin Commission, accessed November 21, 2008, at www.state.nj.us/drbc/spw.htm.

Delaware River Basin Commission, 2008b, Administrative manual, part III-Water quality regulations with amendments through July 16, 2008: West Trenton, N.J., Delaware River Basin Commission, 140 p., accessed November 21, 2008, at www.state.nj.us/drbc/regs/ WQRegs_071608.pdf. 
Fischer, J.M., Riva-Murray, Karen, Hickman, E.R., Chichester, D.C., Brightbill, R.A., Romanok, K.M., and Bilger, M.D., 2004, Water quality in the Delaware River Basin, Pennsylvania, New Jersey, New York, and Delaware, 1998-2001: U.S. Geological Survey Circular 1227, 38 p.

Gburek, W.J., and Folmar, G.J., 1999, Flow and chemical contributions to streamflow in an upland watershed: A baseflow survey: Journal of Hydrology, v. 217, p. 1-18.

Gelbrecht, J., Lengsfeld, H., Pthig, R., and Opitz, D., 2005, Temporal and spatial variation of phosphorous input, retention, and loss in a small catchment of NE Germany: Journal of Hydrology, v. 304, p. 151-165.

Helsel, D.R., and Hirsch, R.M., 1992, Statistical methods in water resources: Amsterdam, Elsevier, 522 p.

Herlihy, A.T., Larsen, D.P., Paulsen, S.G., Urquhart, N.S., and Rosenbaum, B.J., 2000, Designing a spatially balanced, randomized site selection process for the regional stream surveys: The EMAP Mid-Atlantic pilot study: Environmental Monitoring and Assessment, v. 103, p. 5-20.

Insightful Corporation, 2005, S-Plus statistical software, v. 7.0.

Lawrence, G.B., Lincoln, T.A., Horan-Ross, D.A., Olson, M.L., and Waldron, L.A., 1995, Analytical methods of the U.S. Geological Survey's New York District water analysis laboratory: U.S. Geological Survey Open-File Report 95-416, $96 \mathrm{p}$.

Mehaffey, M.H., Nash, M.S., Wade, T.G., Ebert, D.W., Jones, K.B., and Rager, A., 2005, Linking land cover and water quality in New York City's water supply watersheds: Environmental Monitoring and Assessment, v. 107, p. 29-44.

Moore, M.V., Pace, M.L., Mather, J.R., Murdoch, P.S., Howarth, R.W., Folt, C.L., Chen, C.Y., Hemond, H.F., Flebbe, P.A., and Driscoll, C.T., 1997, Potential effects of climate change on freshwater ecosystems of the New England /Mid-Atlantic region: Hydrological Processes, v. 11, p. 925-947.

Murdoch, P.S., Jenkins, J.C., and Birdsey, R.A., eds., 2008, The Delaware River Basin Collaborative Environmental Monitoring and Research Initiative: Foundation document: Newtown Square, Pa., U.S. Department of Agriculture, Forest Service, Northern Research Station, General Technical Report NRS-25, 93 p., accessed August 8, 2008, at http://nrs.fs.fed.us/pubs/gtr/gtr_nrs25.pdf.

Murdoch, P.S., and Shanley, J.B., 2006, Flow-specific trends in river-water quality resulting from the effects of the clean air act in three mesoscale, forested river basins in the northeastern United States through 2002: Environmental Monitoring and Assessment, v. 120, p. 1-25.

Murdoch, P.S., and Stoddard, J.L., 1992, The role of nitrate in the acidification of streams in the Catskill Mountains of New York: Water Resources Research, v. 28, p. 2707-2720.
National Climatic Data Center, 2008, accessed February 8, 2008, at http://www.ncdc.noaa.gov/oa/ncdc.html.

Novick, H.J., 1993, High and Dry? Water politics and the Upper Delaware: Trout, autumn 1993, p. 24-37.

Olsen, A.R., Sedransk, J., Edwards, D., Gotway, C.A., Liggett, W., Rathburn, S., Reckhow, K.H., and Young, L.J., 1999, Statistical issues for monitoring ecological and natural resources in the United States: Environmental Monitoring and Assessment, v. 54, p. 1-45.

Rantz, S.E., and others, 1982, Measurement and computation of streamflow-Volume 2. Computation of discharge: U.S. Geological Survey Water-Supply Paper 2175, 631 p.

Schaffner, M., Evans, M., and Arnott, J., 2007, The June 19, 2007, Delaware County flash flood: A meteorological and hydrological analysis: Binghamton, N.Y., National Oceanic and Atmospheric Administration, National Weather Service, Eastern Region Technical Attachment No. 2008-5, August 2008, 36 p., accessed September 9, 2008, at http:/www.erh. noaa.gov/er/hq/ssd/erps/ta/ta2008-05.pdf.

Smith, A.J., Bode, R.W., and Kleppel, G.S., 2006, A Nutrient Biotic Index (NBI) for use with benthic macroinvertebrate communities: Ecological Indicators, v. 7, p. 371-386.

Smith, A.J., Heitzman, D.L., Abele, L.E., Duffy, B., and Novak, M.A., in press, Standard operating procedures: Biological monitoring of surface waters: Albany, N.Y., New York State Department of Environmental Conservation, Division of Water Resources.

Stoddard, J.L., 1994, Long-term changes in watershed retention of nitrogen: Its causes and aquatic consequences, in Baker, L.A., ed., Environmental chemistry of lakes and reservoirs: Washington, D.C., American Chemical Society Advances in Chemistry Series, v. 237, p. 223-284.

Suro, T.P., Firda, G.D., and Szabo, C.O., 2009, Flood of June 26-29, 2006, Mohawk, Delaware, and Susquehanna River Basins, New York: U.S. Geological Survey Open-File Report 2009-1063, 97 p.

U.S. Census Bureau, 2008, accessed January 20, 2008, at http://www.census.gov/index.html.

U.S. Environmental Protection Agency, 2001, Ambient water quality criteria recommendations: Information supporting the development of State and Tribal nutrient criteria-Rivers and streams in nutrient Ecoregion VIII: U.S. Environmental Protection Agency, Office of Water, EPA-822-B-01-015, December 2001, 28 p. plus app., accessed August 8, 2008, at http://www.epa.gov/ waterscience/criteria/nutrient/ecoregions/rivers/rivers_8.pdf.

U.S. Geological Survey, 2006, Collection of water samples, v. 2.0: U.S. Geological Survey Techniques of WaterResources Investigations, book 9, chap. A4, September, accessed September 17, 2009, at http://pubs.water.usgs.gov/ twri9A4/. 
This page has been left blank intentionally. 


\section{Appendix 1. Land Use in Drainage Areas of Sites Sampled during the Upper Delaware River (UPDE) Study.}

Table 1-1. List of sites with drainage area and land-use percentages.

[ $\mathrm{km}^{2}$, square kilometers; land-use values in percent]

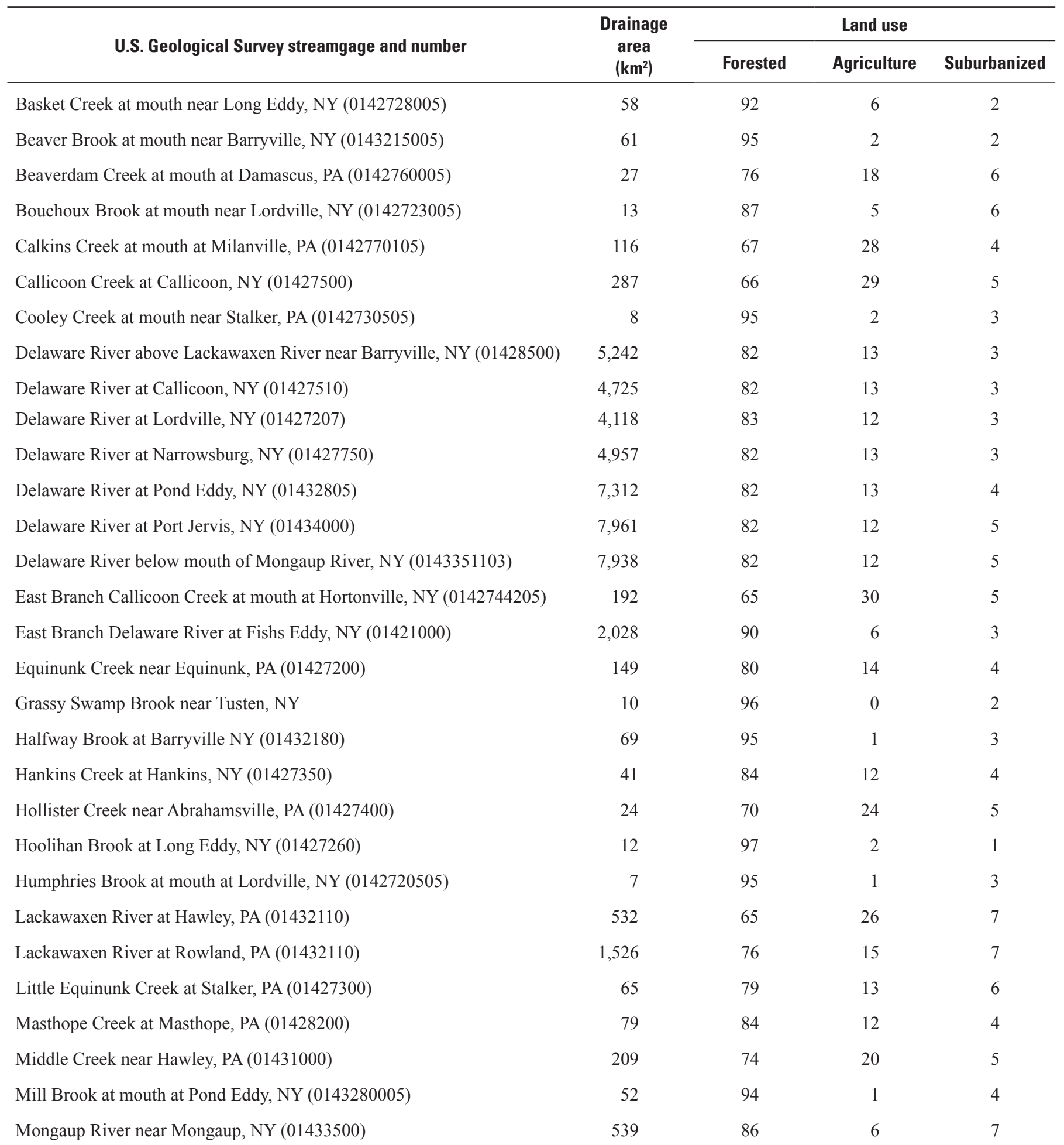


Table 1-1. List of sites with drainage area and land-use percentages.-Continued

$\left[\mathrm{km}^{2}\right.$, square kilometers; land-use values in percent]

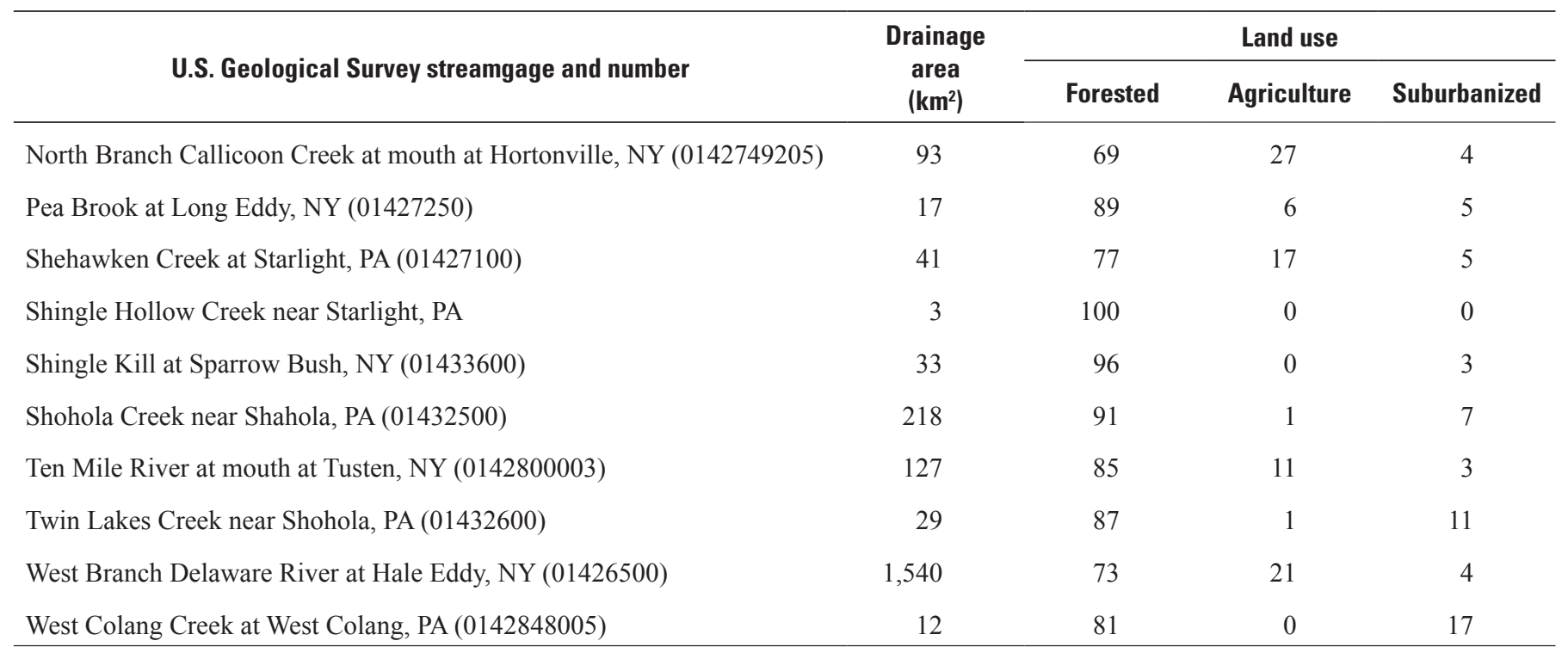




\section{Appendix 2. Water-Quality Statistics for the Intensive and Gradient Study Sites, Upper Delaware River Basin, October 2005 to September 2007.}

\begin{tabular}{lc}
\hline \multicolumn{1}{c}{ Index } & \\
\hline \multicolumn{1}{c}{ U.S. Geological Survey streamgage and number } & Table \\
\hline Callicoon Creek at Callicoon, NY (01427500) & $2-1$ \\
Calkins Creek at mouth at Milanville, PA (0142770105) & $2-2$ \\
Halfway Brook at Barryville, NY (01432180) & $2-3$ \\
Lackawaxen River at Rowland, PA (01432110) & $2-4$ \\
Mill Brook at mouth at Pond Eddy, NY (0143280005) & $2-5$ \\
Mongaup River near Mongaup, NY (01433500) & $2-6$ \\
Twin Lakes Creek near Shohola, PA (01432600) & $2-7$ \\
West Colang Creek at West Colang, PA (0142848005) & $2-8$ \\
East Branch Delaware River at Fishs Eddy, NY (01421000) & $2-9$ \\
West Branch Delaware River at Hale Eddy, NY (01426500) & $2-10$ \\
Delaware River at Callicoon, NY (01427510) & $2-11$ \\
Delaware River above Lackawaxen River near Barryville, NY (01428500) & $2-12$ \\
Delaware River at Port Jervis, NY (01434000) & $2-13$ \\
\hline
\end{tabular}




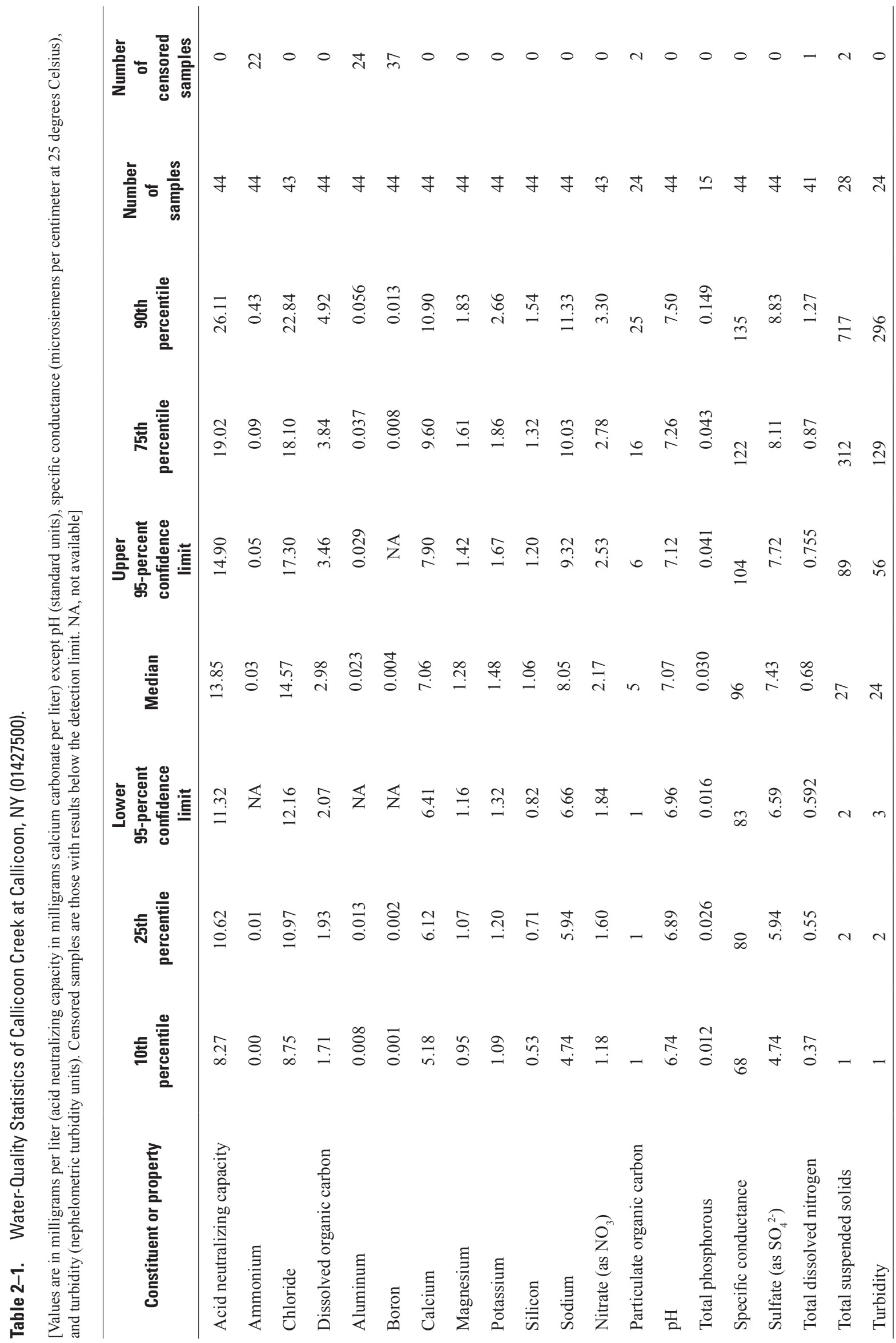




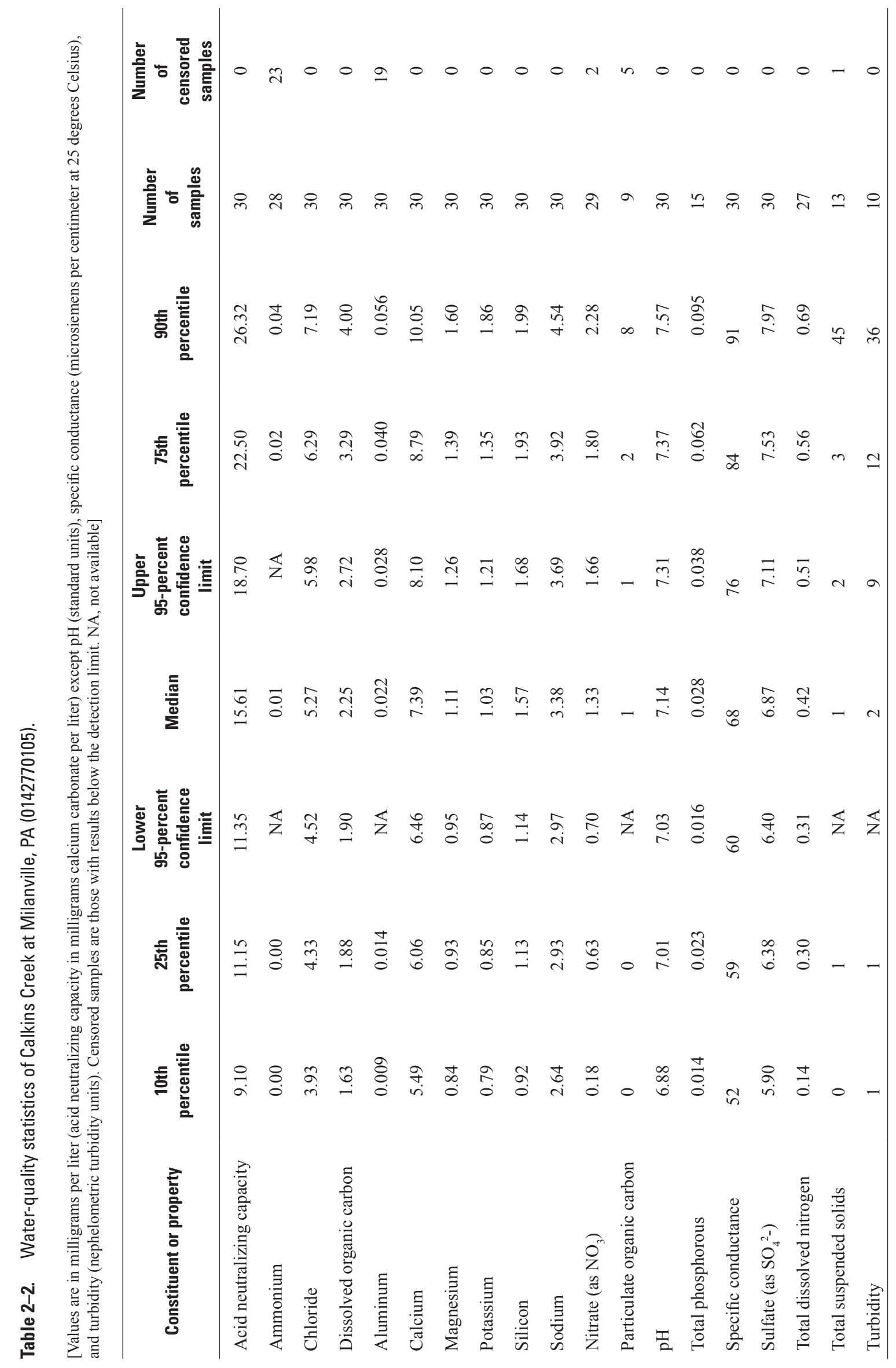




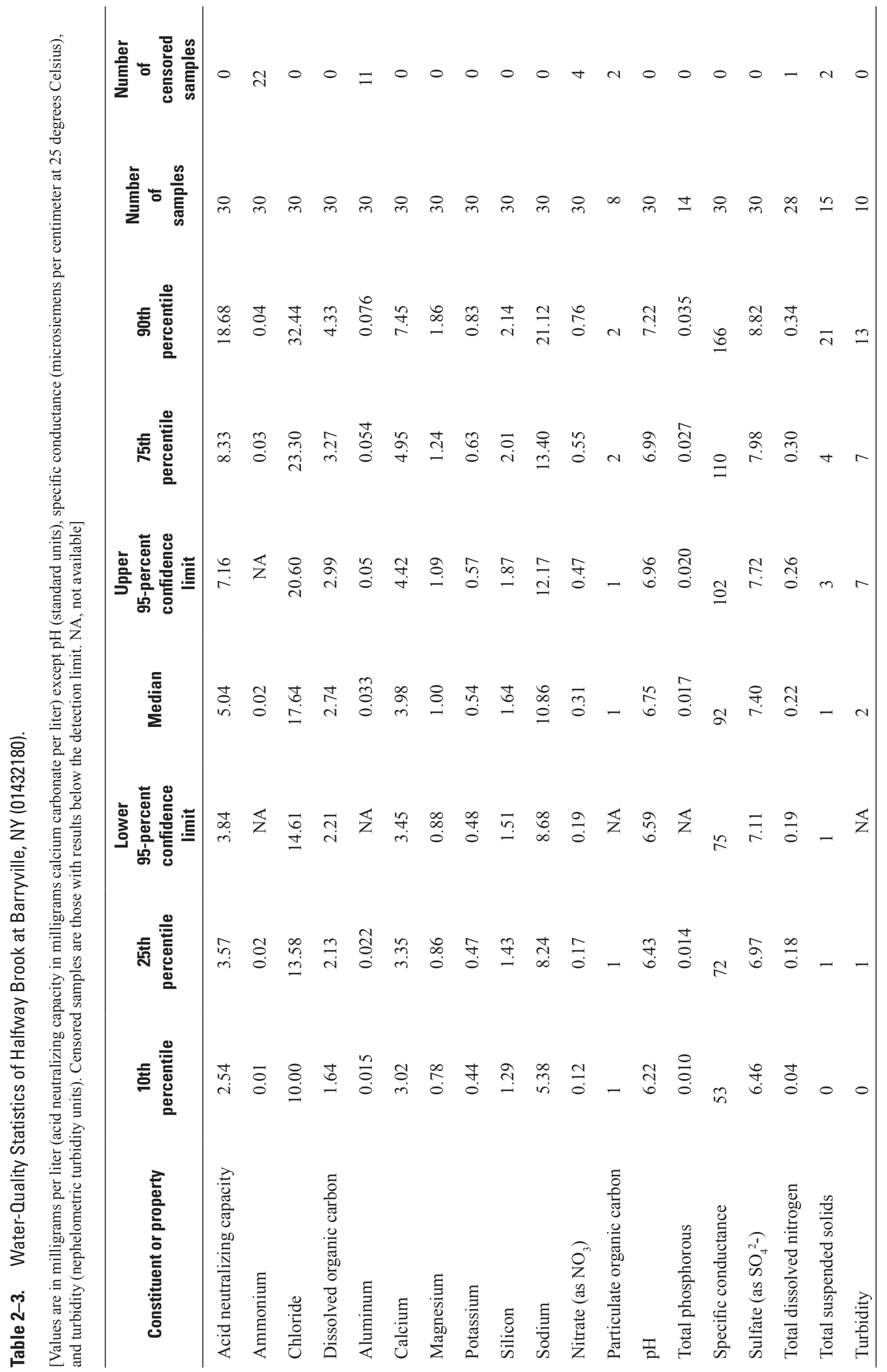




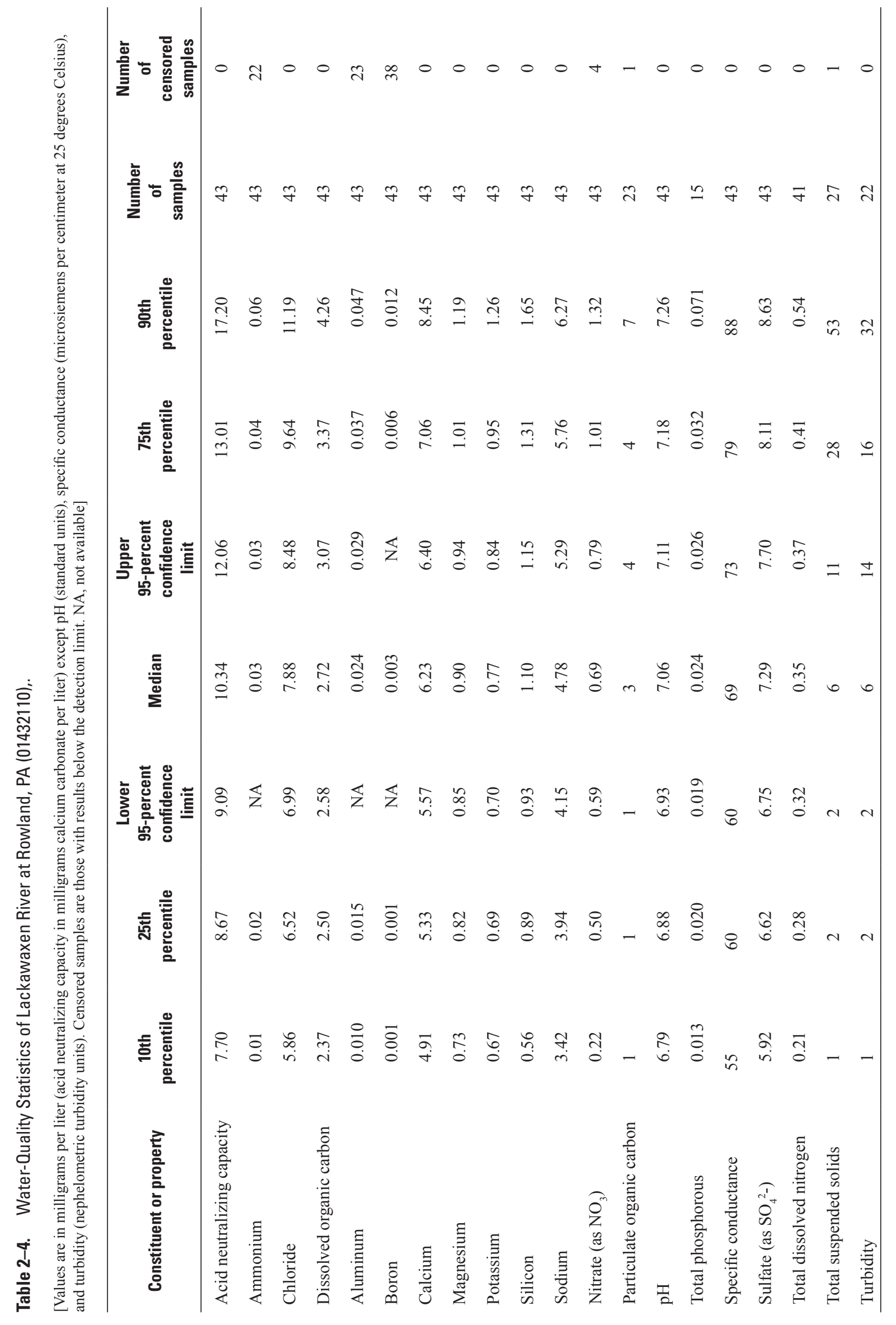




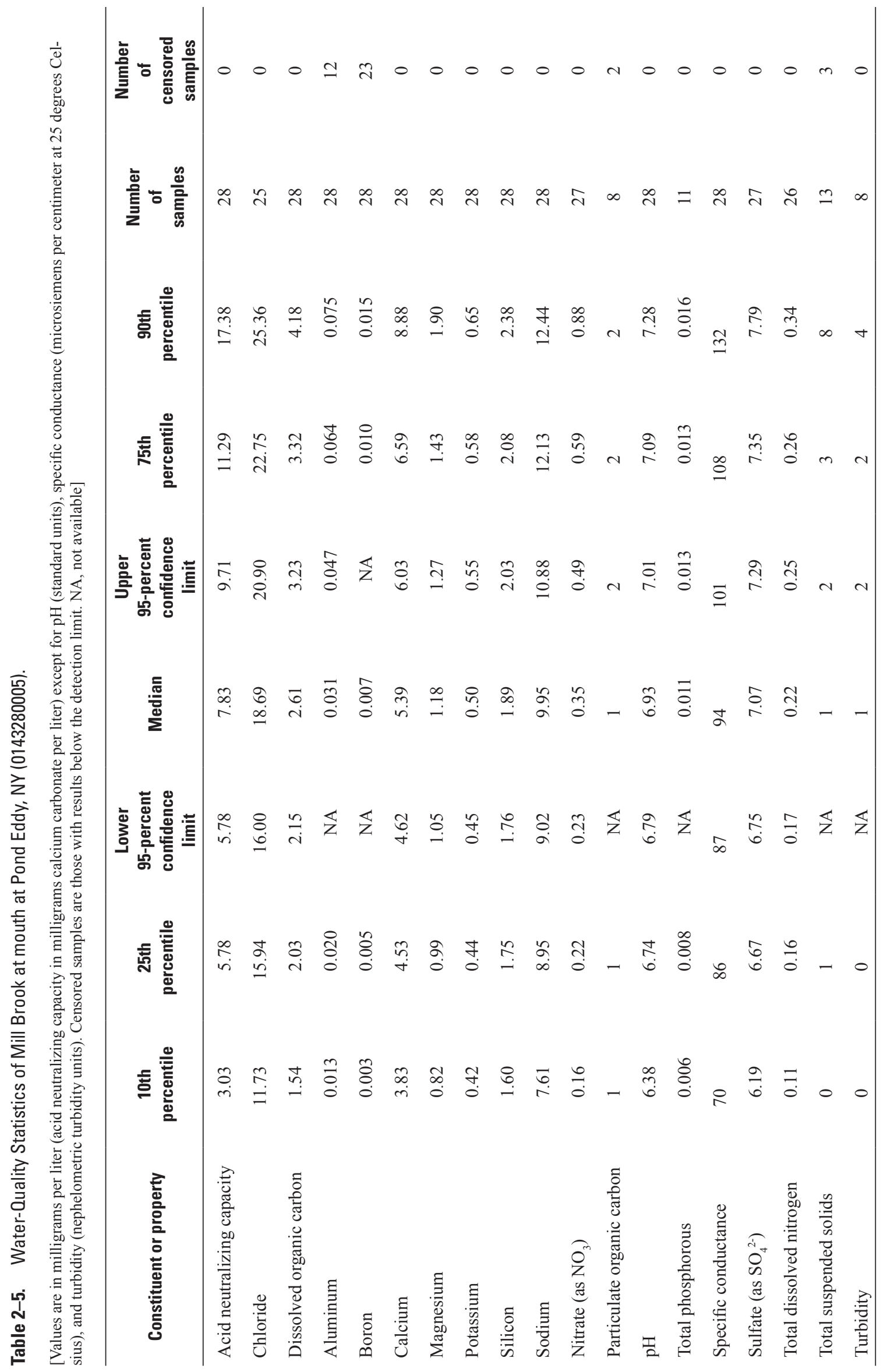




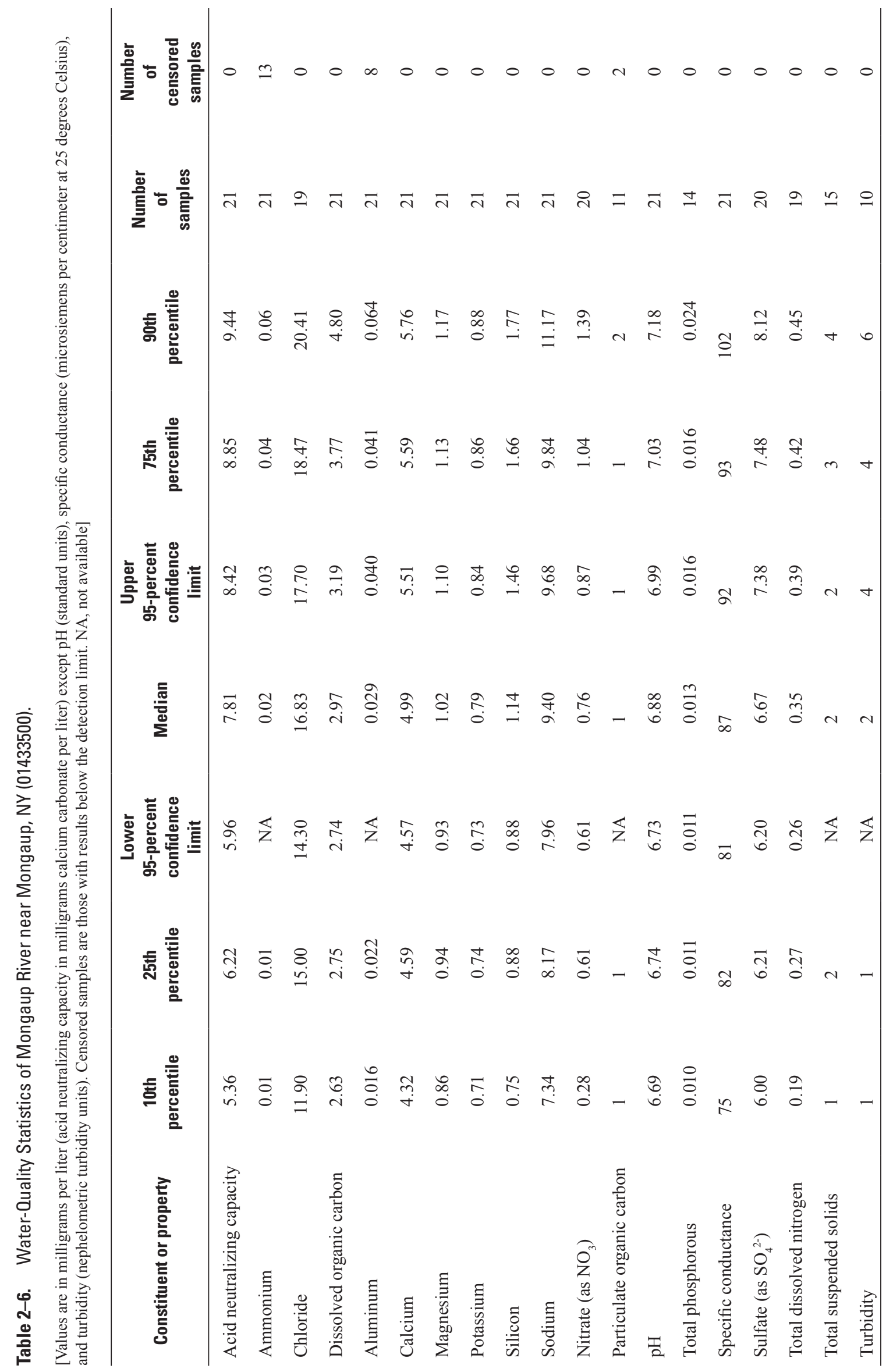




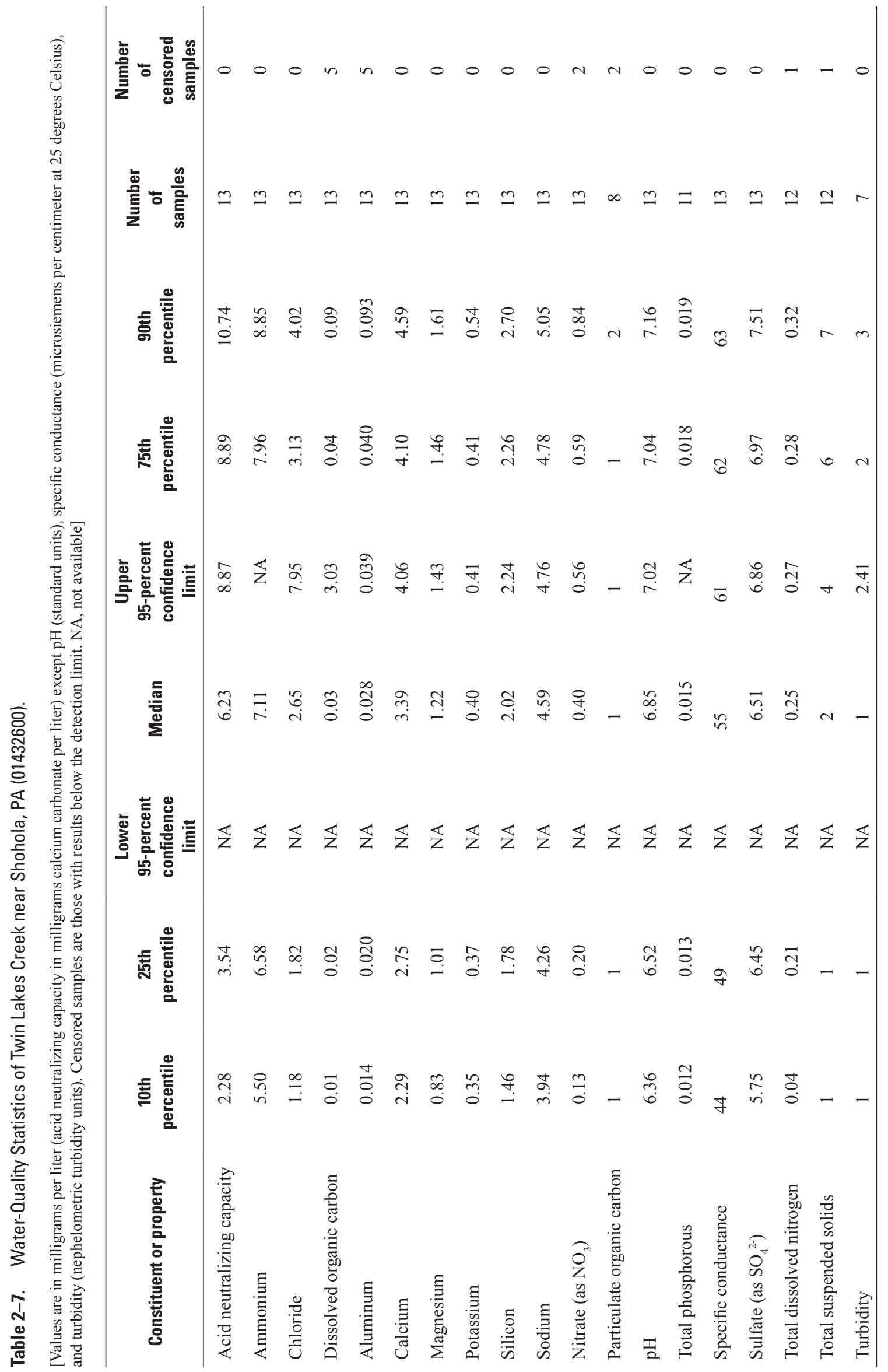




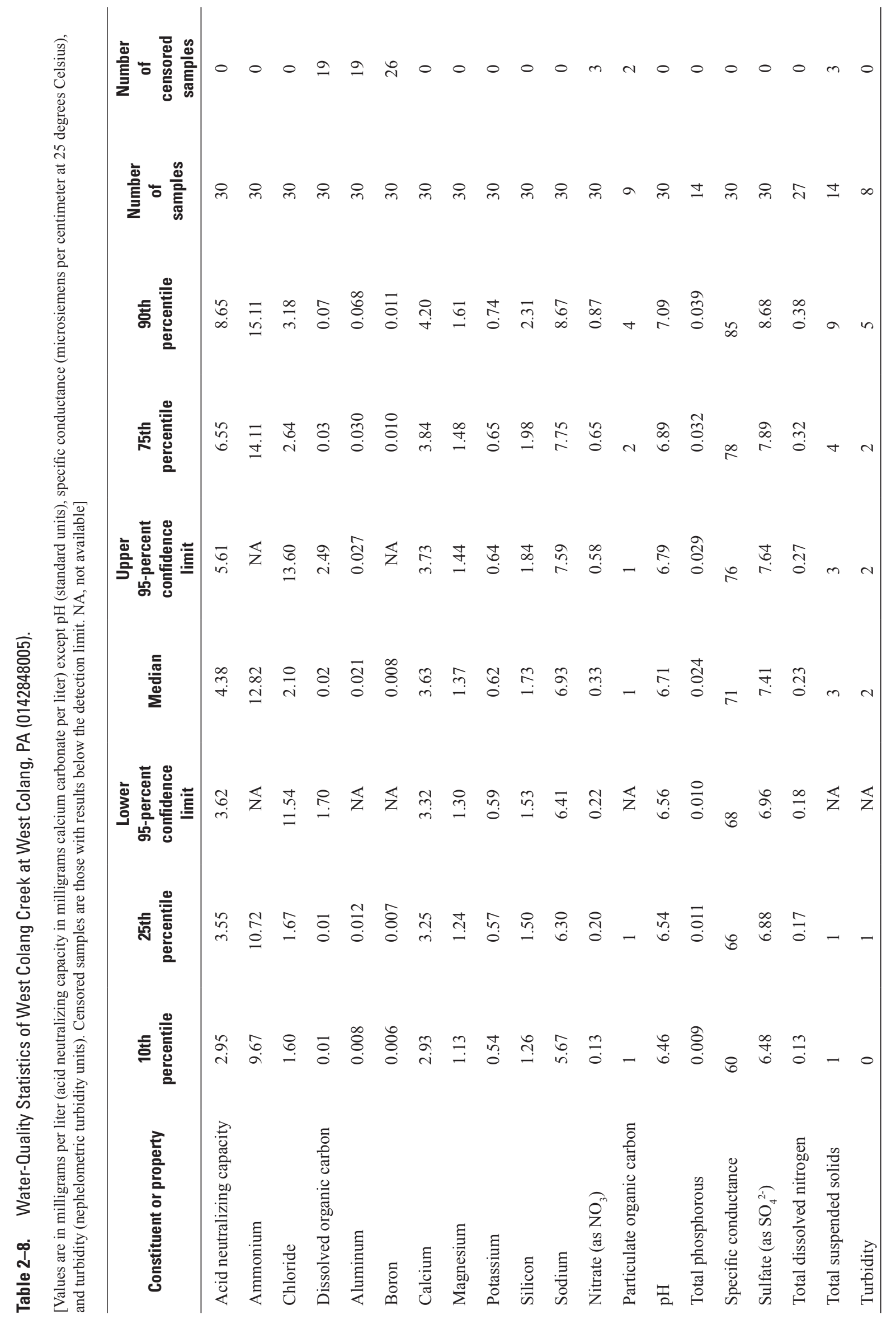




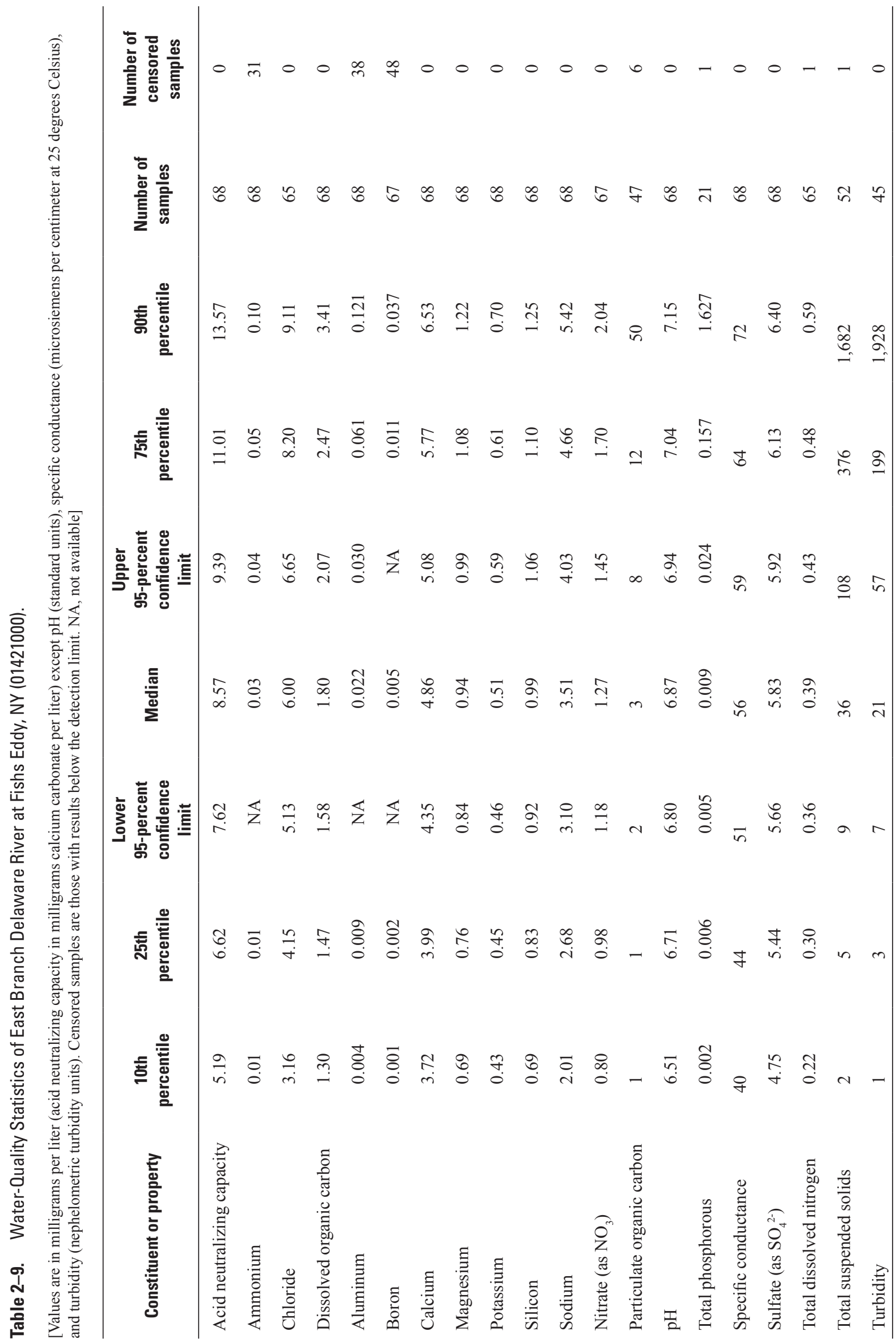




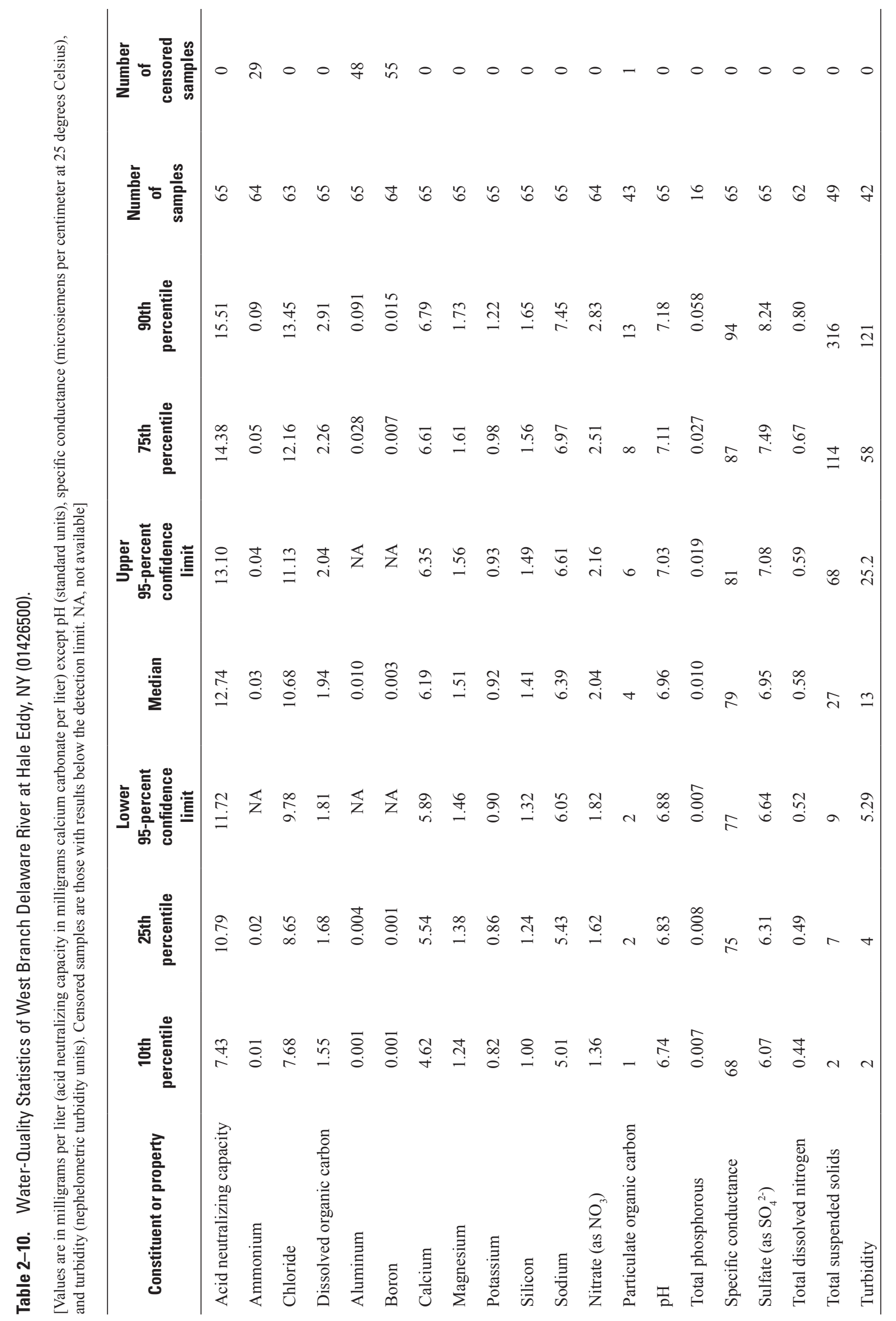




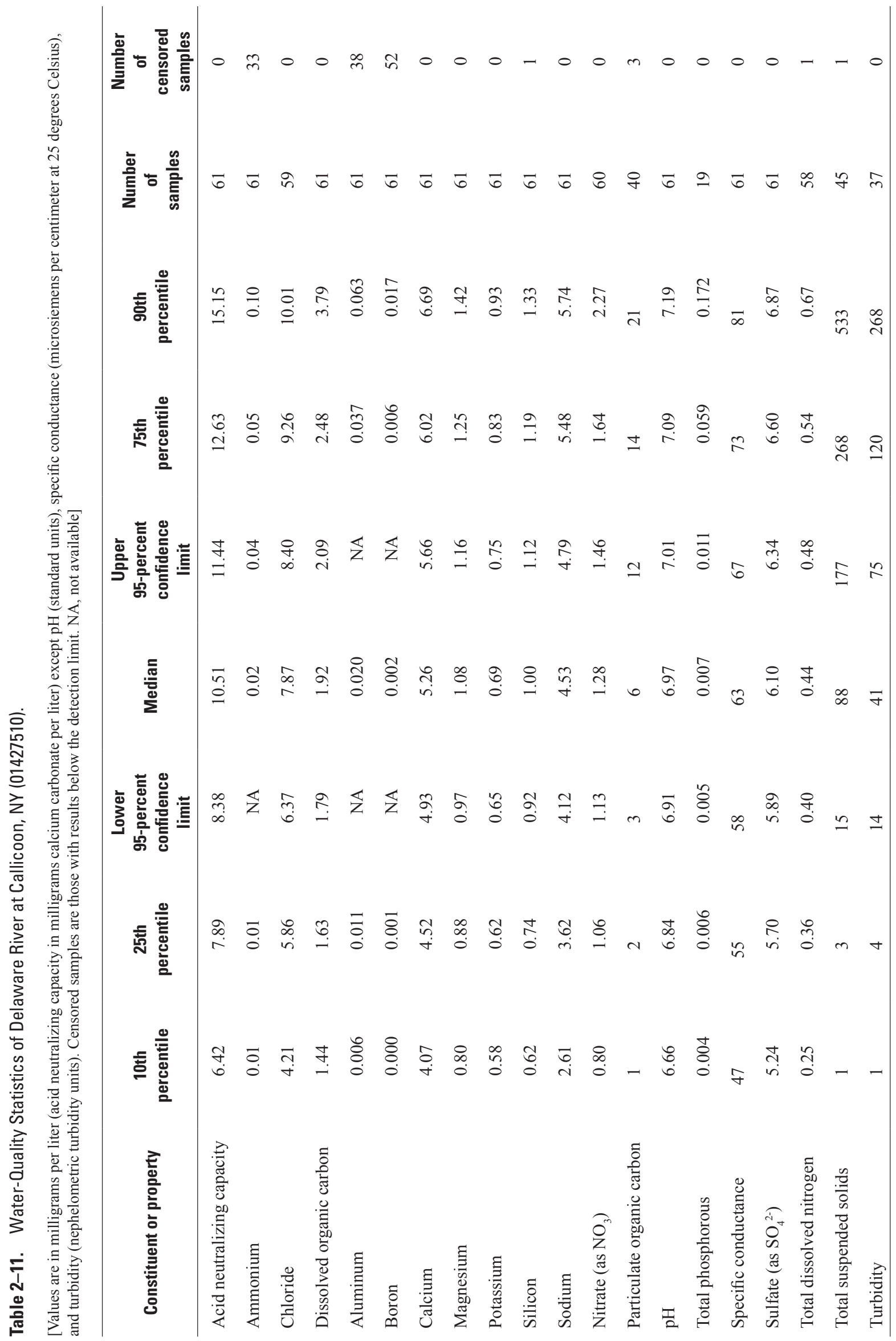




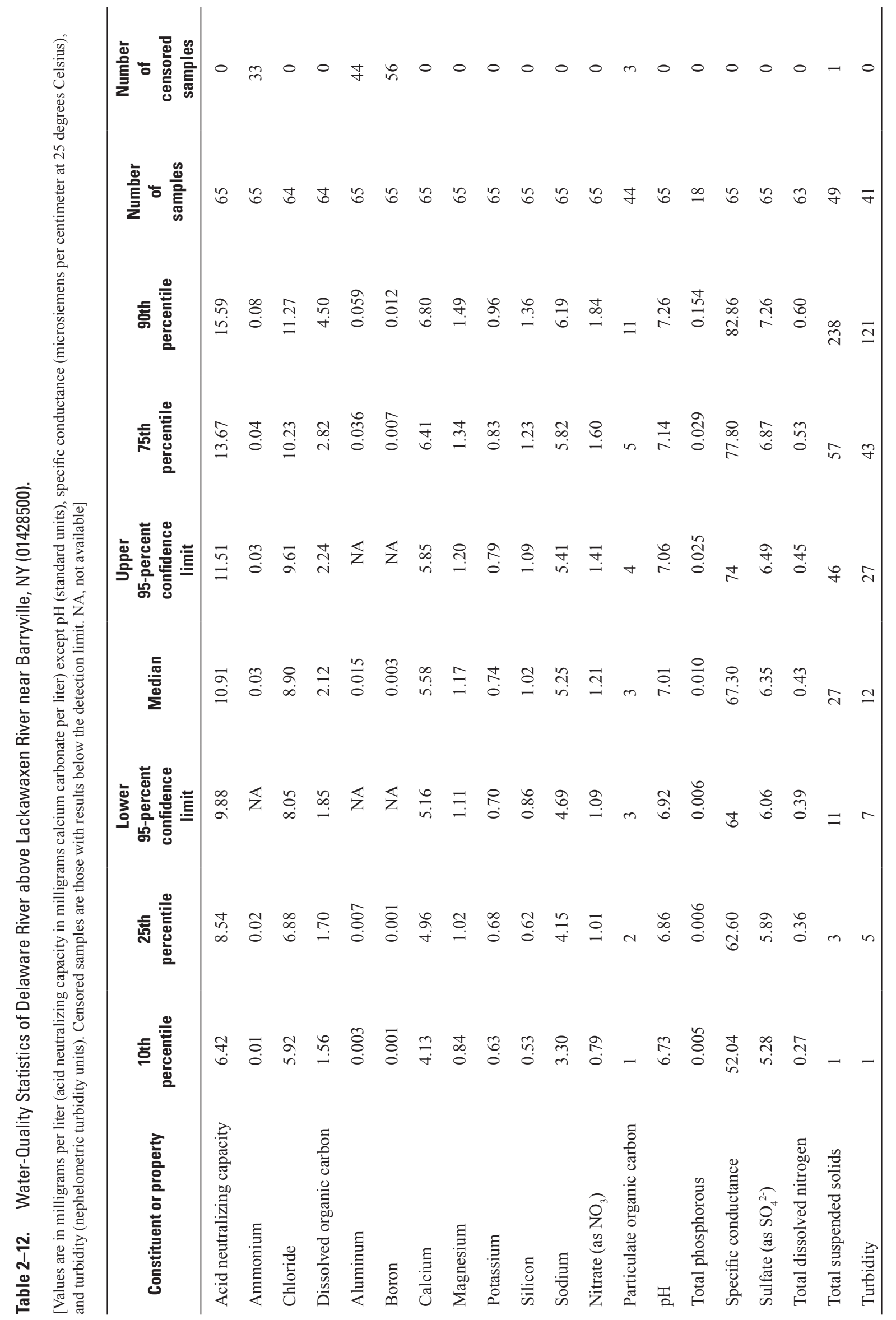




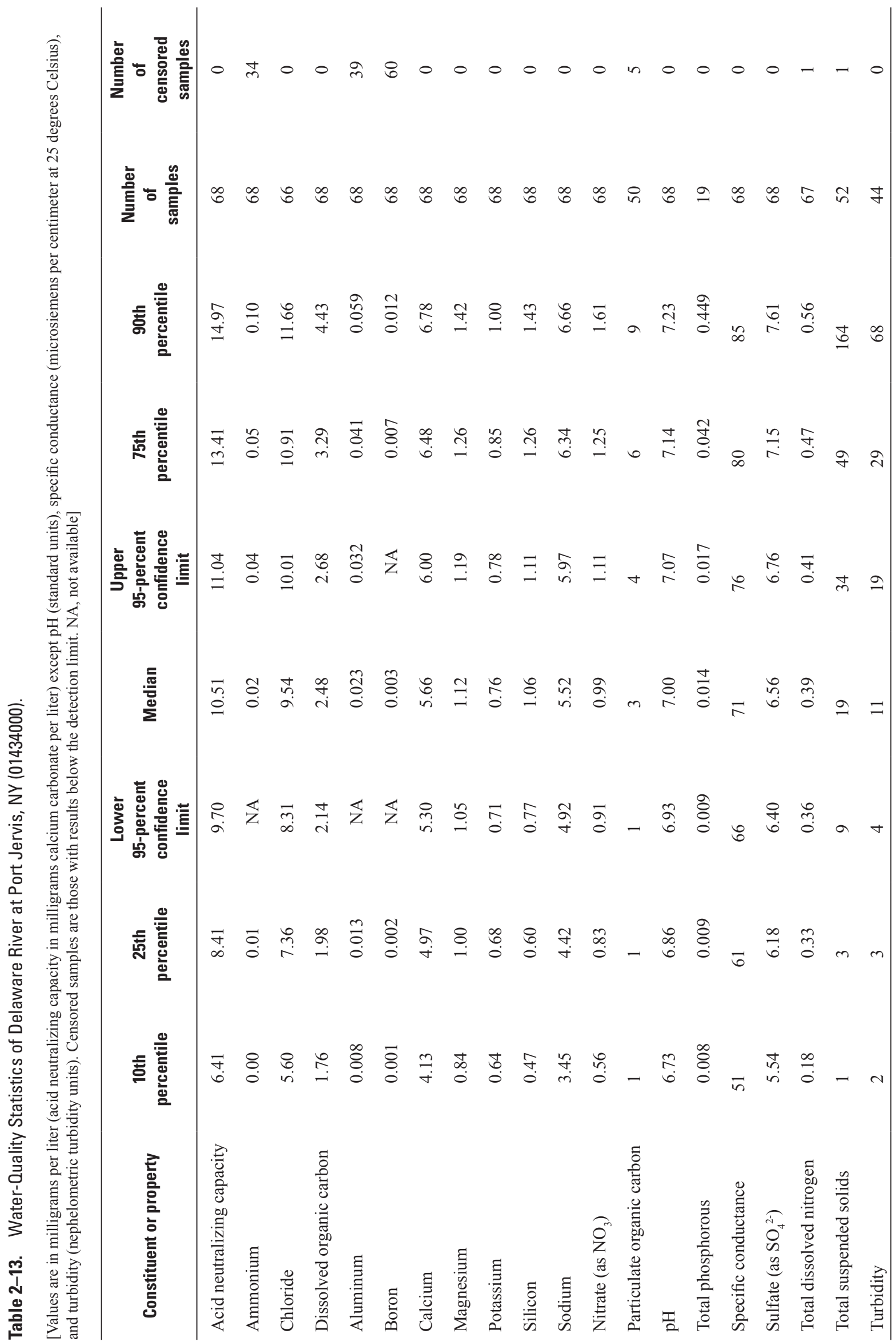


틈

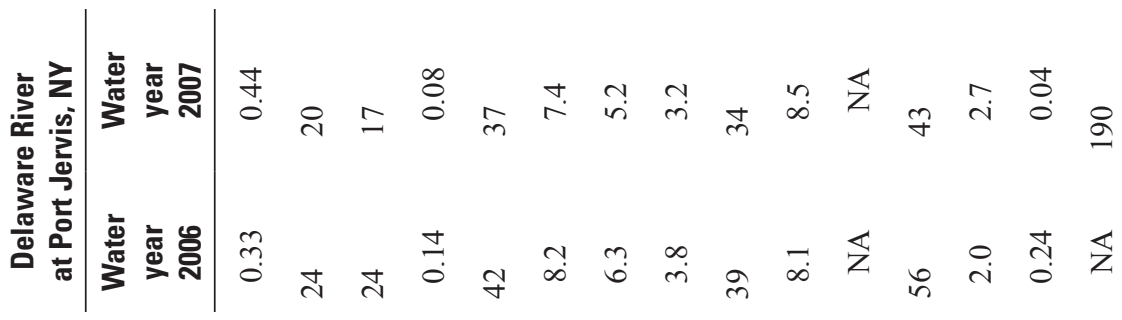

¿

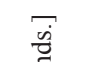

乡ँ

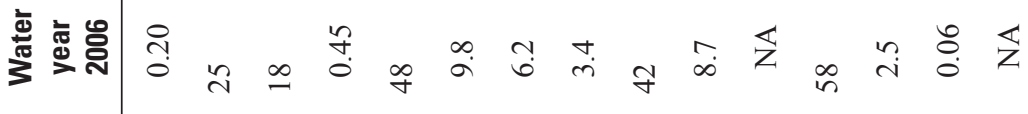

닝

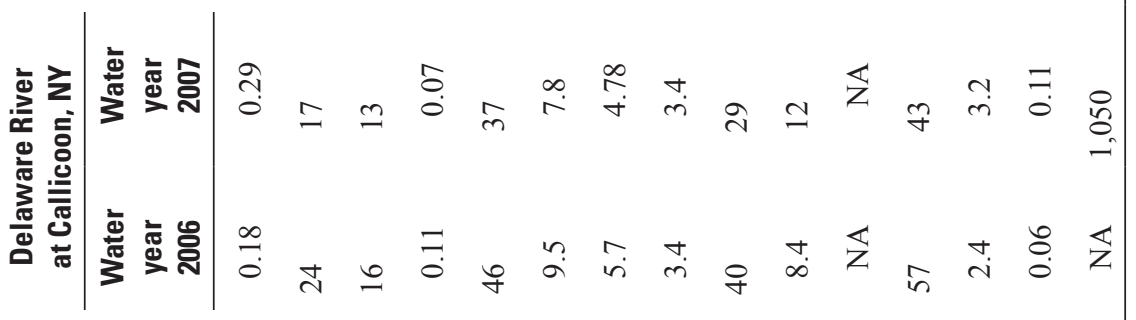

क

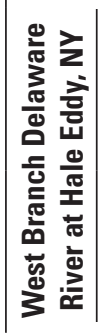

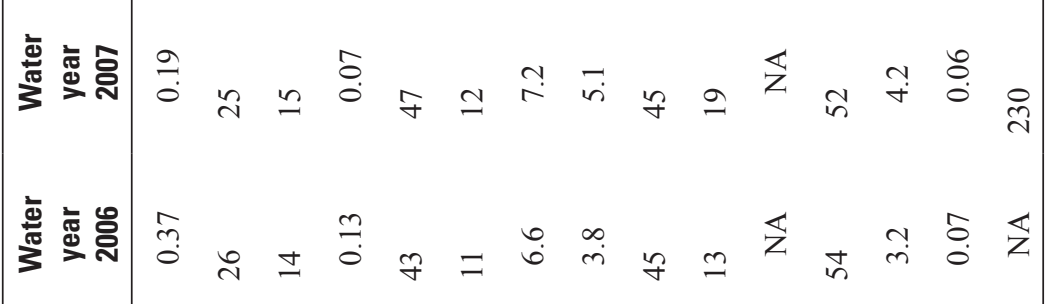

竞咅

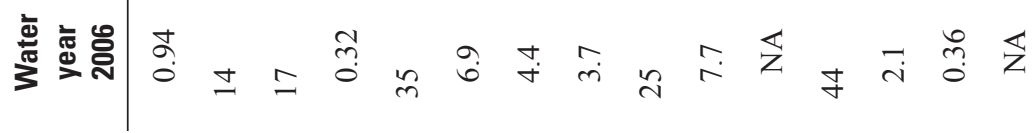

을

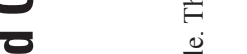

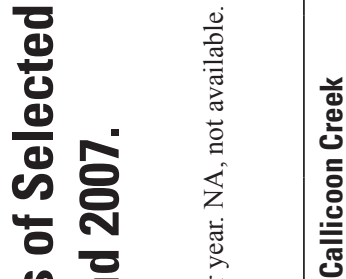

응

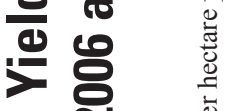

i

m

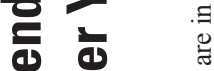

을 $\sum_{i}^{0}$

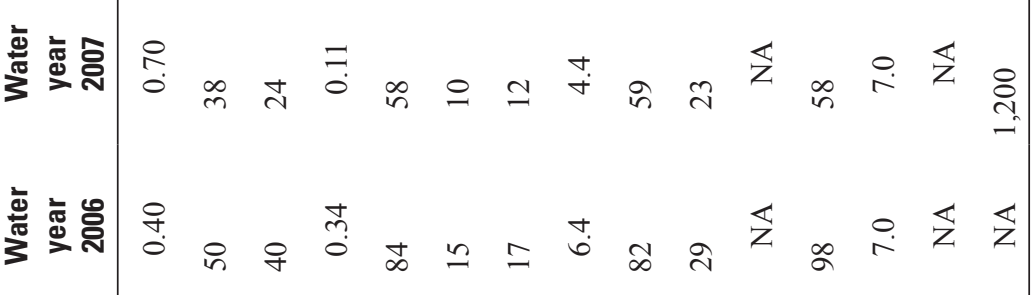

衰

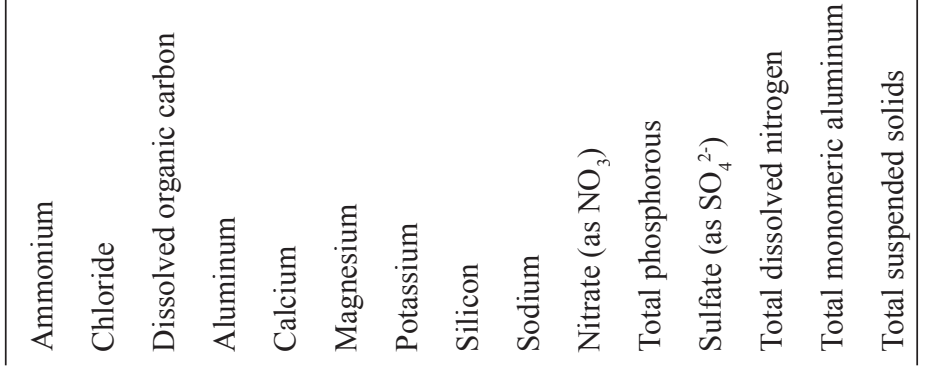


This page has been left blank intentionally. 
Prepared by the Pembroke Publishing Service Center.

For additional information write to:

New York Water Science Center

U.S. Geological Survey

425 Jordan Road

Troy, NY 12180

Information requests:

(518) 285-5602

or visit our Web site at: http://ny.water.usgs.gov 


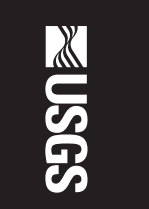

